\title{
From epidemiological synergy to public health Review policy and practice: the contribution of other sexually transmitted diseases to sexual transmission of HIV infection
}

Division of STD

Prevention, National

Center for HIV, STD, and TB Prevention, Centers for Disease

Control and

Prevention, 1600 Clifton Road, Atlanta, GA 30333, USA

D T Fleming ${ }^{\star}$

J N Wasserheit

^Current address: Robert Wood Johnson Medical School, Division of Internal Medicine, 125 Paterson Street, New

Brunswick, NJ 08901, USA.

Correspondence to:

Dr Wasserheit.

Accepted for publication 4 January 1999

Douglas T Fleming, Judith N Wasserheit

Objectives: To review the scientific data on the role of sexually transmitted diseases (STDs) in sexual transmission of HIV infection and discuss the implications of these findings for HIV and STD prevention policy and practice.

Methods: Articles were selected from a review of Medline, accessed with the OVID search engine. The search covered articles from January 1987 to September 1998 and yielded 2101 articles. Methods used to uncover articles which might have been missed included searching for related articles by author, and combing literature reviews. In addition, all abstracts under the category "sexually transmitted diseases" from the XI and XII International Conferences on AIDS (Vancouver 1996 and Geneva 1998) and other relevant scientific meetings were reviewed. Efforts were made to locate journal articles which resulted from the research reported in the identified abstracts. All original journal articles and abstracts which met one of the following criteria were included: (1) studies of the biological plausibility or mechanism of facilitation of HIV infectiousness or susceptibility by STDs, (2) prospective cohort studies (longitudinal or nested case-control) which estimate the risk of HIV infection associated with specific STDs or STD syndromes, or (3) intervention studies which quantitate the effect which STD treatment can have on HIV incidence.

Results: Strong evidence indicates that both ulcerative and non-ulcerative STDs promote HIV transmission by augmenting HIV infectiousness and HIV susceptibility via a variety of biological mechanisms. These effects are reflected in the risk estimates found in numerous prospective studies from four continents which range from 2.0 to 23.5 , with most clustering between 2 and 5 . The relative importance of ulcerative and non-ulcerative STDs appears to be complex. Owing to the greater frequency of non-ulcerative STDs in many populations, these infections may be responsible for more HIV transmission than genital ulcers. However, the limited reciprocal impact of HIV infection on non-ulcerative STDs and the evidence that non-ulcerative STDs may increase risk primarily for the receptive partner (rather than bidirectionally) may modulate the impact of these diseases. The results of two community level randomised, controlled intervention trials conducted in Africa suggest that timely provision of STD services can substantially reduce HIV incidence, but raise additional questions about the optimal way to target and implement these services to achieve the greatest effect on HIV transmission.

Conclusions: Available data leave little doubt that other STDs facilitate HIV transmission through direct, biological mechanisms and that early STD treatment should be part of a high quality, comprehensive HIV prevention strategy. Policy makers, HIV prevention programme managers, and providers should focus initial implementation efforts on three key areas: (i) improving access to and quality of STD clinical services; (ii) promoting early and effective STD related healthcare behaviours; and (iii) establishing surveillance systems to monitor STD and HIV trends and their interrelations.

(Sex Transm Inf 1999;75:3-17)

Keywords: epidemiology; public health policy; sexually transmitted diseases; sexual transmission; HIV

\section{Introduction}

As the interrelation between human immunodeficiency virus (HIV) infection and other sexually transmitted diseases (STDs) has become increasingly well understood, the need to translate these scientific findings into sustainable prevention programmes and policy has become increasingly urgent. In fact, recent evidence that, at a community level, STD treatment can substantially decrease HIV incidence has compelling implications for both STD and HIV prevention, and argues for improved coordination between these often separate efforts.

Recent developments have added complexity and urgency to this topic. For example, technological innovations have made widespread STD screening and treatment easier and more effective, both in industrialised and developing countries. In the United States and several other countries, the epidemiology of HIV itself is changing, with heterosexual transmission accounting for larger proportions of new infections and affecting increasing numbers of women. Furthermore, the advent of new HIV therapies, which promise to transform HIV infection into a "chronic disease," may have already begun to change perceptions about the importance of maintaining safe sexual behaviours. ${ }^{1}$ Finally, new health services research has documented the inadequacy of 
existing STD prevention capacity in the United States, as well as most of the developing world. ${ }^{2-4}$ Clearly, additional approaches to preventing HIV infection are now feasible and necessary.

With these issues in mind, we will review the scientific foundation for our understanding of the role STDs play in facilitating sexual transmission of HIV, focusing on data from studies published since 1990. We will then discuss the implications of these findings for HIV and STD prevention policy and practice by highlighting initial steps in activities such as community based behavioural intervention, surveillance, and clinical services that would help build truly synergistic HIV and STD prevention programmes.

\section{Evidence defining the contribution of other STDs to sexual transmission of HIV infection}

Recent conceptual and empirical work has underlined the reciprocal relation, or "epidemiological synergy," between HIV infection and other STDs, by which each may alter the transmission or manifestations of the other, resulting in a potentially explosive, mutually reinforcing spiral of infection. ${ }^{5}{ }^{6}$ Although this review will focus exclusively on the role of other STDs in facilitating sexual HIV transmission, this relation must be viewed in the context of simultaneous HIV induced alterations in the natural history, diagnosis, or response to therapy of other STDs, and the bidirectional interactions between these effects.

Recent scientific evidence supporting a role for STDs in facilitating HIV transmission has come from three types of studies. Firstly, several studies have examined the biological plausibility of this association, and suggested potential mechanisms at the biological level. Secondly, cohort studies of HIV seroconversion have estimated the increase in risk of HIV infection associated with specific STDs or STD syndromes. Finally, community level intervention studies have begun to quantify the effect that STD treatment can have on HIV incidence. We will discuss each of these lines of evidence in turn.

Articles were selected from a review of Medline, accessed with the OVID search engine. Initial search criteria included all articles on ("sexually transmitted diseases" OR "syphilis" OR "simplexvirus" OR "herpes genitalis" OR "herpesvirus 2, human" OR "sexually transmitted diseases, viral" OR "chancroid" OR "gonorrhoea" OR "neisseria gonorrhoeae" OR "fallopian tube diseases" OR "adnexitis" OR "chlamydia infections" OR "trichomonas" or "trichomonas infections" or "trichomonas vaginalis" OR "trichomonas vaginitis" OR "papillomavirus, human" OR "condyloma acuminata") AND ("HIV" OR "HIV infections" OR "acquired immunodeficiency syndrome"). The OVID search of Medline covered articles from January 1987 to September 1998, and yielded 2101 articles. In addition, a variety of methods was used to uncover articles which might have been missed, including searching for related articles by author, and combing literature reviews. In addition, all abstracts under the category "sexually transmitted diseases" from the XI and XII International Conferences on AIDS (Vancouver 1996 and Geneva 1998) and other relevant scientific meetings were reviewed. Efforts were made to locate journal articles which resulted from the research reported in the abstracts we identified. All original journal articles and abstracts which met one of the following three criteria were included in the review: (1) studies of the biological plausibility or mechanism of facilitation of HIV infectiousness or susceptibility by STDs, (2) prospective cohort studies (longitudinal or nested casecontrol) which estimate the risk of HIV infection associated with specific STDs or STD syndromes, or (3) intervention studies which quantitate the effect which STD treatment can have on HIV incidence. The remaining studies were excluded. These were primarily those that did not directly address relations between HIV and other STDs, and those that employed case-control or cross sectional study designs.

\section{BIOLOGICAL PLAUSIBILITY}

Promotion of HIV transmission by STDs, both ulcerative and non-ulcerative, may occur by a variety of biological mechanisms, which are likely to affect both HIV infectiousness and susceptibility. Firstly, other STDs facilitate HIV shedding in the genital tract, which probably promotes HIV infectiousness. This has been demonstrated by testing genital secretions for the presence of HIV and, more recently, for the HIV concentration. Secondly, STDs also appear to increase susceptibility to HIV, by recruiting HIV susceptible inflammatory cells to the genital tract and by disrupting mucosal barriers to infection. We will discuss each of these effects separately.

The relation between STDs and genital HIV shedding is potentially confounded by the level of immunosuppression, since advancing immunosuppression may promote STD acquisition or persistence, ${ }^{5}$ as well as HIV shedding. ${ }^{7}$ Evidence that the role of STDs is independent of level of immunosuppression comes from studies that adjust for level of immunosuppression in the analysis or demonstrate reduced HIV shedding after STD treatment. Therefore, these considerations are important in assessing the quality and generalisability of the results of this group of studies.

\section{Effect of genital ulcers on HIV infectiousness and susceptibility}

Genital ulcers bleed frequently during sexual intercourse, resulting in potential increases in HIV infectiousness (table 1). In HIV infected individuals, HIV has been detected frequently in genital ulcer exudates. ${ }^{8} 9$ Among 609 HIV-1 positive female sex workers in Cote d'Ivoire, detection of HIV-1 by cervicovaginal lavage was also markedly increased among women with cervicovaginal ulcers compared with those without lesions ( $55.8 \%$ versus $21.5 \%$ ). This effect persisted after adjustment for level of immunosuppression (adjusted odds ratio 
Table 1 Ulcerative STDs and HIV shedding

\begin{tabular}{|c|c|c|c|c|c|}
\hline Author, year & Study population & $\begin{array}{l}\text { Ascertainment of } \\
\text { HIV shedding }\end{array}$ & $\begin{array}{l}\text { Ascertainment of } \\
\text { other STD }\end{array}$ & Results & Comments/study limitations \\
\hline \multicolumn{6}{|l|}{ Female: } \\
\hline $\begin{array}{l}\text { Ghys et al, } \\
1997^{10}\end{array}$ & $\begin{array}{l}609 \text { HIV-1 positive } \\
\text { FSWs in Abidjan. }\end{array}$ & $\begin{array}{l}\text { PCR on } \\
\text { cervicovaginal } \\
\text { lavage (qualitative). }\end{array}$ & $\begin{array}{l}\text { GUD by clinical } \\
\text { exam; } H \text { ducreyi } \\
\text { and HSV culture; } \\
\text { RPR/TPHA. }\end{array}$ & $\begin{array}{l}\text { HIV shedding in } 55.8 \%(29 / 52) \text { FSW with } \\
\text { GUD v } 21.5 \%(120 / 557) \text { without (adj OR } \\
3.9 \text {, CI } 2.1-7.4) \text {. At } 1 \text { week, HIV-1. } \\
\text { detection more frequent if ulcers persisted }\end{array}$ & $\begin{array}{l}\text { HIV-1 shedding significantly } \\
\text { associated with } \\
\text { immunosuppression, which was } \\
\text { included in multivariate analysis. }\end{array}$ \\
\hline $\begin{array}{l}\text { Kreiss et al, } \\
\quad 1989^{8}\end{array}$ & $\begin{array}{l}56 \text { HIV positive FSWs } \\
\text { with GUD in Nairobi. }\end{array}$ & $\begin{array}{l}\text { Culture of ulcer } \\
\text { exudate } \\
\text { (qualitative). }\end{array}$ & $\begin{array}{l}\text { GUD by exam; } H \\
\text { ducreyi culture, } \\
\text { HSV and syphilis } \\
\text { serologies. }\end{array}$ & $\begin{array}{l}\text { HIV cultured from } 11 \%(4 / 36) \text { ulcers (other } \\
\text { cultures not evaluable owing to } \\
\text { contamination). }\end{array}$ & \\
\hline \multicolumn{6}{|l|}{ Male: } \\
\hline Dyer $1998^{11}$ & $\begin{array}{l}86 \text { HIV-1 positive } \\
\text { men with urethritis at } \\
\text { Malawi STD clinic } \\
\text { ( } 24 \text { with GUD). }\end{array}$ & $\begin{array}{l}\text { PCR (NASBA) on } \\
\text { seminal plasma } \\
\text { (quantitative). }\end{array}$ & $\begin{array}{l}\text { GUD by exam; } \\
\text { urethritis, see } \\
\text { Cohen } \text { et al in } \\
\text { Table } 2 \text {. }\end{array}$ & $\begin{array}{l}\text { Median HIV concentration in semen }\left(\times 10^{4}\right. \\
\text { copies/ml): } 21.9,11.0,19.5 \text {, and } 0.4 \text { for } \\
\text { urethritis (all causes) plus GUD, urethritis } \\
\text { alone, NGU plus GUD, and NGU alone, } \\
\text { respectively ( } p=0.04 \text { for NGU plus/minus } \\
\text { GUD). }\end{array}$ & $\begin{array}{l}\text { In multiple linear regression } \\
\text { model with GC and blood } \\
\text { plasma HIV-1 concentration, } \\
\text { GUD not independent predictor } \\
\text { of seminal plasma HIV-1 } \\
\text { concentration. }\end{array}$ \\
\hline $\begin{array}{l}\text { Plummer et } \\
\text { al }, 1990^{9}\end{array}$ & $\begin{array}{l}7 \text { male HIV positive } \\
\text { STD clinic patients } \\
\text { with chancroid in } \\
\text { Nairobi. }\end{array}$ & $\begin{array}{l}\text { Culture and PCR } \\
\text { on ulcer exudate } \\
\text { (qualitative). }\end{array}$ & $H$ ducreyi culture. & $\begin{array}{l}\text { HIV cultured from } 30 \%(2 / 7) \text { ulcer swabs; } \\
86 \% \text { (6/7) ulcer swabs positive for HIV by } \\
\text { PCR. }\end{array}$ & \\
\hline $\begin{array}{l}\text { Schacker } e t \\
a l, 1997^{12}\end{array}$ & $\begin{array}{l}12 \text { HIV positive men } \\
\text { with genital herpes in } \\
\text { Seattle. }\end{array}$ & $\begin{array}{l}\text { PCR on ulcer } \\
\text { exudate } \\
\text { (quantitative). }\end{array}$ & HSV culture. & $\begin{array}{l}\text { HIV detected in } 96 \%(25 / 26) \text { HSV-2 } \\
\text { episodes. HSV by culture correlated with } \\
\text { detection of HIV RNA (OR } 4.6, \text { CI } \\
1.8-8.7) \text {. }\end{array}$ & $\begin{array}{l}\text { HIVquasi-species in ulcers later } \\
\text { appeared in serum, suggesting } \\
\text { replication competence. }\end{array}$ \\
\hline
\end{tabular}

FSW=female sex workers; GUD=genital ulcer disease; PCR=polymerase chain reaction; NGU=non-gonococcal urethritis; GC=gonorrhoea; OR=odds ratio; $\mathrm{CI}=$ confidence interval.

(OR), 3.9, 95\% confidence interval (CI) 2.1-7.4). Among the limited number of women with ulcers who returned after approximately 1 week, successful treatment reduced HIV-1 detection to levels similar to those among women who did not have ulcers at enrolment. ${ }^{10}$ Among $86 \mathrm{HIV}-1$ infected men presenting to a Malawi STD clinic with urethritis, the presence of genital ulcer disease (GUD) increased HIV concentration in seminal plasma, particularly among those with non-gonococcal urethritis (NGU) (median copy number $\times 10^{4} 19.5 v 0.4$ for NGU plus GUD $v$ NGU alone). ${ }^{11}$ However, in contrast with the findings in Cote d'Ivoire, GUD was not an independent predictor of seminal HIV shedding, but instead appeared to increase viral load in semen by increasing blood plasma HIV concentrations, possibly because GUD patients had more advanced HIV disease or systemic immune activation. ${ }^{11}$ In another recent study, detection of replication competent HIV from herpetic genital ulcers was common, and was correlated with recovery of HSV-2 by culture from the lesions. ${ }^{12}$ These findings are consistent with recent evidence that HIV transcription and plasma viral load may increase during acute episodes of HSV-1 infections. ${ }^{13}$

Conversely, among HIV seronegative individuals, genital ulcers may increase susceptibility to HIV by disrupting mucosal integrity, and by increasing the presence and activation of HIV susceptible cells in the genital tract. ${ }^{14}{ }^{15}$ Haemophilus ducreyi, for example, evokes a cell mediated immune response which attracts HIV susceptible cells to the ulcer surface. ${ }^{16}$ In fact, $H$ ducreyi may contain specific $T$ cell stimulating antigens, ${ }^{17}$ which may further predispose $\mathrm{T}$ cells to infection by HIV. In addition, with viral STDs such as herpes, there may be interactions between viruses in the genital tract which promote the establishment of HIV infection. For example, in tissues co-infected with HSV-1,
HIV-1 virions appear able to infect keratinocytes that lack CD4 receptors and, therefore, are not usually vulnerable to HIV infection. ${ }^{18}$ In gaining access to cells, HIV may also take advantage of changes in cellular chemokine receptors that result from infection with other viruses, as shown recently in studies of cytomegalovirus. ${ }^{19}$

\section{Effect of non-ulcerative STDs on HIV}

infectiousness and susceptibility

Non-ulcerative STDs such as gonorrhoea and chlamydia also increase HIV shedding in the genital tract (table 2), probably by recruiting HIV infected inflammatory cells as part of the normal host response. Among HIV positive men in Nairobi, prevalence of detectable HIV in genital secretions increased in the presence of gonorrhoea (adjusted OR 3.2, 95\% CI 1.66.4) and, with successful therapy, was halved from $44 \%$ to $21 \%$, a level similar to the $19 \%$ found among men without urethritis at enrolment. ${ }^{20}$ In a US study, seminal leucocytosis also predicted HIV detection in semen (adjusted OR 7.0, 95\% CI 1.3-39.3). ${ }^{21}$ In addition, several studies in men have documented an association between non-ulcerative STDs and increased concentration of HIV shedding by showing that HIV nucleic acid copy number in semen is elevated in the presence of non-ulcerative STDs. ${ }^{22-24}$ In the largest of these studies, involving $135 \mathrm{HIV}-1$ positive men in Malawi, median HIV-1 concentrations in seminal plasma were eight and 10 times higher among men with urethritis and gonorrhoea, respectively, than among men without urethritis. ${ }^{23}$ Two weeks after appropriate treatment, HIV-1 concentrations among urethritis patients were reduced by two thirds to levels that were not significantly different from those among controls without urethritis $(p=0.9)$.

Among women, data linking non-ulcerative STDs and HIV shedding are more preliminary, but growing rapidly. Investigators in Mombasa, 
Table 2 Non-ulcerative STDs and HIV shedding

\begin{tabular}{|c|c|c|c|c|c|}
\hline Author, year & Study population & $\begin{array}{l}\text { Ascertainment of } \\
\text { HIV shedding }\end{array}$ & Ascertainment of other STD & Results & Comments/study limitations \\
\hline \multicolumn{6}{|l|}{ Female: } \\
\hline $\begin{array}{l}\text { Clemetson } \\
\text { et al, } \\
1993^{26}\end{array}$ & $\begin{array}{l}97 \text { female HIV } \\
\text { positive STD } \\
\text { clinic patients in } \\
\text { Nairobi. }\end{array}$ & $\begin{array}{l}\text { PCR on } \\
\text { endocervical } \\
\text { and vaginal } \\
\text { swabs } \\
\text { (qualitative). }\end{array}$ & $\begin{array}{l}\text { Cervical mucopus on } \\
\text { exam; cervical GS and } \\
\text { GC culture; vaginal wet } \\
\text { mount and GS. }\end{array}$ & $\begin{array}{l}\text { HIV shedding associated with mucopus } \\
\text { (MPC in } 22 \% \text { of } 27 \text { HIV shedders } v 7 \% \text { of } \\
56 \text { non-shedders; adj OR } 6.2 \text {, CI } 0.9-41.4 \text { ); } \\
\text { association with } 6 \text { GC cases NS (unadj OR } \\
4.3 \text {, CI } 0.7-25.3 \text { ). }\end{array}$ & $\begin{array}{l}\text { Multivariate model included age, } \\
\text { OCP use, pregnancy, cervical } \\
\text { ectopy, and mucopus (not } \\
\text { immunosuppression). }\end{array}$ \\
\hline $\begin{array}{l}\text { Ghys et al, } \\
1997^{10}\end{array}$ & $\begin{array}{l}609 \text { HIV-1 } \\
\text { positive FSWs in } \\
\text { Abidjan. }\end{array}$ & $\begin{array}{l}\text { PCR on cervico- } \\
\text { vaginal lavage } \\
\text { (qualitative). }\end{array}$ & $\begin{array}{l}\text { Cervical mucopus on } \\
\text { exam; CT EIA, GC } \\
\text { culture, vaginal wet } \\
\text { mount. }\end{array}$ & $\begin{array}{l}\text { HIV shedding associated with GC and CT } \\
\text { (HIV detected in } 34.5 \% \text { of } 194 \text { with GC } v \\
19.9 \% \text { of } 403 \text { without, adj OR } 1.9, \text { CI } \\
1.2-3.0 ; 48.2 \% \text { of } 27 \text { with CT } v 23.5 \% \text { of } \\
563 \text { without, adj OR } 2.5 \text {, CI } 1.1-5.8 \text { ). } \\
\text { HIV- } 1 \text { shedding reduced if STD cured. }\end{array}$ & $\begin{array}{l}\text { HIV-1 shedding significantly } \\
\text { associated with } \\
\text { immunosuppression, which was } \\
\text { included in multivariate analysis. }\end{array}$ \\
\hline $\begin{array}{l}\text { Kreiss et al, } \\
\quad 1994^{27}\end{array}$ & $\begin{array}{l}92 \text { HIV positive } \\
\text { FSWs in Nairobi. }\end{array}$ & $\begin{array}{l}\text { PCR on endo- } \\
\text { cervical swabs } \\
\text { (qualitative). }\end{array}$ & $\begin{array}{l}\text { Cervical mucopus on } \\
\text { exam; cervical GS and } \\
\text { Pap; CT and GC culture. }\end{array}$ & $\begin{array}{l}\text { HIV shedding associated with cervicitis by } \\
\text { GS or Pap (adj OR 8.7, CI } 2.0-37.2 \text { ), but } \\
\text { not with cervical mucopus, GC, or CT. }\end{array}$ & $\begin{array}{l}\text { Multivariate model included OCP } \\
\text { use, cervicitis, pregnancy, cervical } \\
\text { maturation value (not } \\
\text { immunosuppression). }\end{array}$ \\
\hline $\begin{array}{l}\text { John et al, } \\
\qquad 1997^{28}\end{array}$ & $\begin{array}{l}223 \text { HIV-1 } \\
\text { positive pregnant } \\
\text { women in } \\
\text { Nairobi. }\end{array}$ & $\begin{array}{l}\text { PCR on cervical } \\
\text { and vaginal } \\
\text { swabs } \\
\text { (qualitative). }\end{array}$ & $\begin{array}{l}\text { Cervical mucopus on } \\
\text { exam; GC culture, CT } \\
\text { antigen detection, vaginal } \\
\text { KOH prep and GS, T } \\
\text { vaginalis PCR. }\end{array}$ & $\begin{array}{l}\text { HIV shedding associated with mucopus } \\
\text { (MPC in } 44 \% \text { of } 63 \mathrm{HIV} \text { shedders } v 28 \% \\
\text { of non-shedders, OR } 2.1 \text {, CI } 1.1-3.9) \text {. GC } \\
\text { (OR 2.2, CI } 0.7-6.4 \text { ) and CT (OR } 1.2 \text {, CI } \\
0.4-3.4 \text { ) associations NS. }\end{array}$ & $\begin{array}{l}\text { HIV detection associated with low } \\
\text { CD4 count, but no multivariate } \\
\text { analysis provided to adjust for } \\
\text { immunosuppression. }\end{array}$ \\
\hline $\begin{array}{l}\text { Mostad et } \\
\quad \text { al, } 1997^{25}\end{array}$ & $\begin{array}{l}318 \text { female } \\
\text { HIV-1positive } \\
\text { STD clinic } \\
\text { patients in } \\
\text { Mombasa, } \\
\text { Kenya. }\end{array}$ & $\begin{array}{l}\text { PCR on } \\
\text { endocervical } \\
\text { and vaginal } \\
\text { swabs } \\
\text { (qualitative). }\end{array}$ & $\begin{array}{l}\text { Vaginal and cervical GS, } \\
\text { GC and } T \text { vaginalis } \\
\text { culture, CT EIA, } \\
\text { RPR/TPHA. }\end{array}$ & $\begin{array}{l}\text { HIV shedding associated with GC, and } \\
\text { cervicitis and vaginitis by GS, but not CT } \\
\text { or trich (HIV detected in } 75 \% \text { with GC } v \\
49 \% \text { without, } p=0.02 \text { ). }\end{array}$ & $\begin{array}{l}\text { No multivariate analysis of STD, } \\
\text { cervicitis, or vaginitis data } \\
\text { presented. }\end{array}$ \\
\hline \multicolumn{6}{|l|}{ Male: } \\
\hline $\begin{array}{l}\text { Anderson } \\
\text { et al, } \\
1992^{21}\end{array}$ & $\begin{array}{l}95 \text { HIV positive } \\
\text { men in Boston } \\
\text { and San } \\
\text { Francisco. }\end{array}$ & $\begin{array}{l}\text { Semen culture } \\
\text { (qualitative). }\end{array}$ & Seminal leucocyte counts. & $\begin{array}{l}\text { HIV detection associated with seminal } \\
\text { leucocytosis (adj OR 7.0, CI 1.3-39.3). }\end{array}$ & $\begin{array}{l}\text { Multivariate model included } \\
\text { CD } 4<200 \text {, symptomatic HIV } \\
\text { disease, zidovudine therapy, and } \\
\text { seminal leucocytosis. }\end{array}$ \\
\hline $\begin{array}{l}\text { Atkins et al, } \\
1996^{22}\end{array}$ & $\begin{array}{l}4 \text { HIV positive } \\
\text { men with } \\
\text { urethritis ( } 3 \text { with } \\
\text { GC and } 1 \text { with } \\
\text { NGU) in } \\
\text { London. }\end{array}$ & $\begin{array}{l}\text { PCR on semen } \\
\text { (quanitative). }\end{array}$ & $\begin{array}{l}\text { Urethral Gram stain, GC } \\
\text { culture. }\end{array}$ & $\begin{array}{l}\text { STD treatment reduced average HIV } \\
\text { proviral DNA load from approx } 450-150 \\
\text { copies per ml of semen }(\mathrm{p}<0.05)\end{array}$ & $\begin{array}{l}\text { HIV proviral loads estimated from } \\
\text { graph; exact values not provided in } \\
\text { article. }\end{array}$ \\
\hline $\begin{array}{l}\text { Cohen et al, } \\
1997^{23}\end{array}$ & $\begin{array}{l}135 \text { male HIV-1 } \\
\text { positive } \\
\text { dermatology and } \\
\text { STD clinic } \\
\text { patients in } \\
\text { Malawi. }\end{array}$ & $\begin{array}{l}\text { PCR (NASBA) } \\
\text { on seminal } \\
\text { plasma } \\
\text { (quantitative). }\end{array}$ & $\begin{array}{l}\text { Urethral Gram stain, GC, } \\
\text { and T, vaginalis culture, } \\
\text { CT LCR. }\end{array}$ & $\begin{array}{l}\text { Median HIV concentration in semen }\left(\times 10^{4}\right. \\
\text { copies } / \mathrm{ml}): 15.8,12.4 \text { and } 1.5 \text { in men with } \\
\text { GC, urethritis (all causes), and no } \\
\text { urethritis, respectively; } 2 \text { weeks after STD } \\
\text { treatment, } 4.1(\mathrm{p}=0.0001) .\end{array}$ & $\begin{array}{l}\text { Men with and without urethritis } \\
\text { had similar CD } 4 \text { and blood plasma } \\
\text { HIV RNA levels. }\end{array}$ \\
\hline $\begin{array}{l}\text { Eron et al } \\
1996^{24}\end{array}$ & $\begin{array}{l}1 \text { HIV-1 positive } \\
\text { man with } \\
\text { chlamydia in } \\
\text { Chapel Hill, NC. }\end{array}$ & $\begin{array}{l}\text { PCR (NASBA) } \\
\text { on seminal } \\
\text { plasma } \\
\text { (quantitative). }\end{array}$ & CT culture. & $\begin{array}{l}\text { CT treatment reduced HIV RNA in semen } \\
\text { from } 1200000 \text { to } 12000 \text { copies per } \mathrm{ml} \text { (a } \\
100 \text {-fold reduction). }\end{array}$ & Case report. \\
\hline $\begin{array}{l}\text { Moss et al, } \\
1995^{20}\end{array}$ & $\begin{array}{l}106 \text { male HIV } \\
\text { positive STD } \\
\text { clinic patients in } \\
\text { Nairobi. }\end{array}$ & $\begin{array}{l}\text { PCR on urethral } \\
\text { exudate } \\
\text { (qualitative). }\end{array}$ & $\begin{array}{l}\text { Urethral Gram stain, GC } \\
\text { culture. }\end{array}$ & $\begin{array}{l}\text { HIV shedding associated with GC (adj OR } \\
3.2 \text {, CI } 1.6-6.4 \text { ); prevalence of HIV } \\
\text { shedding reduced to baseline (from } 44 \% \text { to } \\
21 \%, p=0.02 \text { ) after GC treatment. }\end{array}$ & $\begin{array}{l}\text { Multivariate model included age, } \\
\text { CD } 4 \text { count }<200 \text {, and GC. HIV } \\
\text { shedding increased with } \\
\text { immunosuppression. }\end{array}$ \\
\hline
\end{tabular}

Gc=gonorrhoea; NGU=non-gonococcal urethritis; GS=Gram stain; CT=Chlamydia trachomatis; EIA=enzyme immunoassay; RPR=rapid plasma reagin; $\mathrm{TPHA}=$ Treponema pallidum haemagglutiation assay; $\mathrm{LCR}=$ ligase chain reaction; $\mathrm{MPC}=$ mucopurulent cervicitis; $\mathrm{OCP}=\mathrm{oral}$ contraceptive pills.

Kenya found that HIV shedding was associated with gonorrhoea (univariate OR 3.1 (95\% CI 1.1-9.8), and Gram stain evidence of cervicitis or vaginitis, but not with chlamydial or trichomonal infection. ${ }^{25}$ In the Cote d'Ivoire study mentioned above, after adjustment for level of immunosuppression in multivariate analysis, HIV was at least twice as frequently detected among women with gonorrhoea or chlamydia as among women without these STDs. The results of successful treatment of the 83 women with gonorrhoea in this study were reminiscent of the findings among men in Nairobi co-infected with HIV and gonorrhoea: the prevalence of HIV shedding fell from $42 \%$ to $24 \%(\mathrm{p}<0.01)$. HIV shedding also decreased from $50 \%$ to $38 \%$ among the 16 women successfully treated for chlamydia, but the decrease did not achieve statistical significance. ${ }^{10}$

Although two studies of Nairobi prostitutes showed no statistically significant associations between specific STDs and HIV shedding, these studies did suggest a strong correlation between HIV detection and cervical mucopus (adjusted OR $6.2,95 \%$ CI $0.9-41.4)^{26}$ or cervical inflammation by Gram stain or $\mathrm{Pa}-$ panicolaou smear (adjusted OR 8.7, 95\% CI 2.0-37.2). ${ }^{27}$ The authors speculate that extremely frequent gonococcal infection and treatment with antibiotics among their subjects may have hampered their ability to detect true associations. ${ }^{27}$

Among pregnant women, genital HIV shedding has an additional dimension, the potential for increased transmission from mother to child during delivery. Pregnancy itself appears to promote HIV shedding. ${ }^{26}{ }^{27}$ In a recent study of pregnant women, HIV detection in genital secretions was also associated with cervical mucopus, but not with gonococcal or chlamydial cervicitis. ${ }^{28}$

In HIV negative individuals, non-ulcerative STDs appear to increase susceptibility to HIV 
Table 3 Prospective studies of genital ulcer disease (GUD) (mixed or unspecified aetiology) and HIV seroconversion

\begin{tabular}{|c|c|c|c|c|}
\hline $\begin{array}{l}\text { Author, year } \\
\text { (design) }\end{array}$ & $\begin{array}{l}\text { Study population (number of } \\
\text { HIV seroconverters) }\end{array}$ & $\begin{array}{l}\text { Ascertainment of GUD (number of } \\
\text { cases) }\end{array}$ & Risk estimates (95\% CI) & Comments/study limitations \\
\hline \multicolumn{5}{|c|}{ Female to male transmission: } \\
\hline $\begin{array}{l}\text { Cameron et al, } \\
1989^{33} \\
\text { (cohort) }\end{array}$ & $\begin{array}{l}293 \text { men with STDs } \\
\text { acquired from FSWs in } \\
\text { Nairobi, Kenya ( } 24 \text { SC). }\end{array}$ & $\begin{array}{l}\text { H ducreyi culture, dark field, } \\
\text { syphilis serology ( } 149 \text { cases). }\end{array}$ & Adj RR: 4.7 (1.3-17.0). & $\begin{array}{l}\text { Adjusted for sexual behaviour, but limited } \\
\text { behavioral data included. }\end{array}$ \\
\hline $\begin{array}{l}\text { Mbizvo et al, } \\
1996^{33 \mathrm{~A}} \\
\text { (cohort) }\end{array}$ & $\begin{array}{l}1607 \text { male factory workers } \\
\text { in Harare, Zimbabwe ( } 51 \\
\text { SC). }\end{array}$ & $\begin{array}{l}\text { Self reported genital ulcer ( } 39 \\
\text { cases). }\end{array}$ & $\begin{array}{l}\text { Adj Cox hazard ratio } 3.6 \\
(1.5-8.3) \text {. }\end{array}$ & $\begin{array}{l}\text { Adjusted for sexual behaviour, but no } \\
\text { objective STD diagnosis. }\end{array}$ \\
\hline $\begin{array}{l}\text { Nelson et al, } \\
1997^{35} \\
\text { (nested case } \\
\text { control) }\end{array}$ & $\begin{array}{l}169 \text { male Thai military } \\
\text { conscripts ( } 45 \text { SC; } 124 \\
\text { controls). }\end{array}$ & $\begin{array}{l}H \text { ducreyi, HSV-2, and syphilis } \\
\text { serology ( } 73,98 \text {, and } 5 \text { cases, } \\
\text { respectively). }\end{array}$ & $\begin{array}{l}\text { Adj OR } 2.2(0.9-5.5) \text { for } H \text { ducreyi } \\
\text { seropositivity; NS for syphilis (see } \\
\text { table } 4 \text { for HSV-2). }\end{array}$ & $\begin{array}{l}\text { Few syphilis cases; careful attention to } \\
\text { adjustment for sexual behaviour. }\end{array}$ \\
\hline $\begin{array}{l}\text { Nopkesorn et al, } \\
1998^{34} \\
\text { (cohort) }\end{array}$ & $\begin{array}{l}1036 \text { male Thai military } \\
\text { conscripts ( } 14 \text { SC). }\end{array}$ & $\begin{array}{l}\text { Self reported GUD during and } 3 \\
\text { years before study ( } 210.5 \text { and } \\
308.4 \text { person years, respectively); } \\
H \text { ducreyi, HSV-2, and syphilis } \\
\text { serologies. }\end{array}$ & $\begin{array}{l}\text { Adj RR } 13.5 \text { (3.4-89.9) for } \\
\text { incident GUD; unadj RR } 5.4 \\
\text { (1.6-20.3) for GUD in } 3 \text { years } \\
\text { before study; NS for } H \text { ducreyi } \\
\text { seropositivity at enrolment. }\end{array}$ & $\begin{array}{l}\text { Low HIV incidence; potential bias due to } \\
54 \% \text { loss to follow up; serological analyses } \\
\text { limited by focus on specimens obtained at } \\
\text { enrolment; adjusted for FSW contact and } \\
\text { receptive anal intercourse. }\end{array}$ \\
\hline $\begin{array}{l}\text { Telzak et al, } \\
1993^{36} \\
\text { (cohort) }\end{array}$ & $\begin{array}{l}758 \text { heterosexual male STD } \\
\text { clinic patients in NYC } \\
\text { without history of IDU ( } 14 \\
\text { SC). }\end{array}$ & $\begin{array}{l}\text { Clinical exam, dark field, } \\
\text { RPR/MHATP, } H \text { ducreyi culture, } \\
\text { Tzank smear ( } 344 \text { cases). }\end{array}$ & $\begin{array}{l}\text { Adj OR } 3.3 \text { (1.1-10.1) for } \\
\text { chancroid; NS for syphilis and } \\
\text { HSV (compares GUD patients } \\
\text { with those with non GUD STDs). }\end{array}$ & $\begin{array}{l}\text { Potential selection bias due to response } \\
\text { rate and recruitment strategy; potential } \\
\text { misclassification bias due to lack of HSV } \\
\text { culture or serology and frequent clinical } \\
\text { diagnosis of chancroid. }\end{array}$ \\
\hline \multicolumn{5}{|c|}{ Male to female transmission: } \\
\hline $\begin{array}{l}\text { Plummer et al, } \\
1991^{37} \\
\text { (cohort) }\end{array}$ & $\begin{array}{l}124 \text { FSWs in Nairobi, } \\
\text { Kenya ( } 83 \text { SC). }\end{array}$ & $\begin{array}{l}\text { Clinical exam, } H \text { ducreyi culture, } \\
\text { syphilis serology ( } 71 \text { cases). }\end{array}$ & Adj OR 3.3 (1.2-10.1). & $\begin{array}{l}\text { Dose-response relation between GUD } \\
\text { and HIV seroconversion; potential bias } \\
\text { due to } 37 \% \text { loss to follow up. }\end{array}$ \\
\hline \multicolumn{5}{|c|}{ Both routes of transmission: } \\
\hline $\begin{array}{l}\text { DeVincenzi et } \\
\text { al, 1994 } \\
\text { (cohort) }\end{array}$ & $\begin{array}{l}256 \text { HIV serodiscordant } \\
\text { couples in Europe (12 SC). }\end{array}$ & Self reported GUD ( 5 cases). & $\begin{array}{l}\text { Unadj incidence ratio } 5.2 \\
(4.4-6.0) \text {. }\end{array}$ & $\begin{array}{l}\text { No clinical or lab confirmation of STD } \\
\text { diagnosis; no adjustment for sexual } \\
\text { behaviour. }\end{array}$ \\
\hline $\begin{array}{l}\text { Kassler et al, } \\
1994^{39} \\
\text { (nested case } \\
\text { control) }\end{array}$ & $\begin{array}{l}147 \text { STD clinic patients } \\
\text { tested twice for HIV in } \\
\text { Baltimore (49 SC; } 98 \\
\text { matched controls). }\end{array}$ & $\begin{array}{l}\text { Clinical exam, RPR from chart } \\
\text { review ( } 7 \text { cases). }\end{array}$ & Adj OR 11.3 (1.6-80.2). & $\begin{array}{l}\text { Retrospective cohort from convenience } \\
\text { sample of patients tested twice for HIV; } \\
\text { limited data on sexual behaviour. }\end{array}$ \\
\hline $\begin{array}{l}\text { Mehendale et al, } \\
1995^{40} \text { (cohort) }\end{array}$ & $\begin{array}{l}851 \text { STD clinic patients in } \\
\text { Pune, India ( } 62 \text { SC). }\end{array}$ & $\begin{array}{l}\text { Clinical exam ( } 55 \% \text { of cohort } \\
\text { diagnosed with GUD). }\end{array}$ & $\begin{array}{l}\text { Adj RR } 4.3(2.2-8.4) \text { for GUD at } \\
\text { visit before seroconversion; } 8.2 \\
(3.8-17.9) \text { for recurrent GUD. }\end{array}$ & Potential bias due to $26 \%$ response rate. \\
\hline
\end{tabular}

$\mathrm{SC}=$ seroconverters; $\mathrm{RPR}=$ rapid plasma reagin; $\mathrm{MHATP}=$ microhaemagglutination assay for antibodies to Treponema pallidum; $\mathrm{RR}=\mathrm{risk}$ ratio; $\mathrm{NS}=\mathrm{not}$ significant; $\mathrm{OR}=$ odds ratio.

by recruiting HIV target cells to the endocervix. For example, the median concentration of endocervical CD4 lymphocytes was almost twice as high among $32 \mathrm{HIV}$ negative STD clinic patients with gonorrhoea, chlamydia, or trichomoniasis as among 32 patients without these infections (476 v 245 per 10000 cells, $\mathrm{p}<0.001) .^{29}$ In addition, in vitro data suggest that Chlamydia trachomatis not only recruits polymorphonuclear leucocytes, but may also interact with these cells to increase HIV replication. ${ }^{30}$

SEROCONVERSION STUDIES

Recent prospective studies of new HIV infections in the presence of STDs have made the leap from biological plausibility to observed phenomenon. In the majority of these studies, to document the temporal sequence of STD acquisition and HIV seroconversion, groups of initially HIV negative people were followed with repeated physical examinations and HIV tests, although some studies relied on self reports of STDs. Importantly, a number of these studies included enough seroconversions to control for sexual behaviour as a potential confounder of the relation between STDs and HIV infection. We will discuss only prospective studies, and will emphasise those that used objective STD detection methods and adjusted for sexual behaviour. For summaries of casecontrol and cross sectional studies, we refer the reader to several recent reviews. ${ }^{5132}$
Genital ulcer disease of mixed or unspecified aetiology and HIV transmission

Nine prospective studies address genital ulcer disease (GUD) of mixed or unspecified aetiology (table 3). In this group of studies, the authors presented measures of risk of HIV seroconversion associated with genital ulcers, regardless of aetiology. Overall, six of these nine studies used an objective STD detection method to document active infection (that is, clinical or laboratory examination) and adjusted for sexual behaviour. All six showed a strong effect of GUD on HIV acquisition, with adjusted odds ratios or risk ratios between 2.2 and 11.3 .

Five of these studies address female to male HIV transmission. Cameron and colleagues ${ }^{33}$ studied 293 men who had acquired an STD from female sex workers in Nairobi, Kenya. The ulcers they acquired were primarily (89\%) chancroid. Overall, 24 men seroconverted to HIV, and those with ulcers were almost five times as likely to acquire HIV as those without GUD, even after adjustment for sexual behaviour. A second study, conducted among factory workers in Zimbabwe, also reported a more than threefold increase in risk of HIV seroconversion among those with self reported genital ulcers, despite the study's limitation of failing to use clinical or laboratory methods to detect GUD. ${ }^{33 \mathrm{~A}}$ Two studies conducted in Thailand examined cohorts of male conscripts during their 2 years of military service. One of these, a cohort study of 1036 men of whom 14 became 
Table 4 Prospective studies of genital herpes (HSV) and HIV seroconversion

\begin{tabular}{|c|c|c|c|c|}
\hline Author, year (design) & $\begin{array}{l}\text { Study population (number of } \\
\text { HIV seroconverters) }\end{array}$ & $\begin{array}{l}\text { Ascertainment of } H S V \\
\text { (number of cases) }\end{array}$ & Risk estimates (95\% CI) & Comments/study limitations \\
\hline \multicolumn{5}{|c|}{ Female to male transmission: } \\
\hline $\begin{array}{l}\text { Nelson et al, } 1998^{35} \\
\quad \text { (nested case } \\
\text { control) }\end{array}$ & $\begin{array}{l}169 \text { male Thai military } \\
\text { conscripts ( } 45 \text { SC; } 124 \\
\text { controls). }\end{array}$ & $\begin{array}{l}\text { HSV-2 antibody ( } 98 \\
\text { cases). }\end{array}$ & Adj OR 3.1 (1.2-7.9). & $\begin{array}{l}\text { Randomly selected controls; careful } \\
\text { attention to adjustment for sexual behaviour. }\end{array}$ \\
\hline $\begin{array}{l}\text { Nopkesorn et al, } \\
1998^{34} \text { (cohort) }\end{array}$ & $\begin{array}{l}1036 \text { male Thai military } \\
\text { conscripts ( } 14 \text { SC). }\end{array}$ & $\begin{array}{l}\text { HSV-2 antibody (166 } \\
\text { cases). }\end{array}$ & $\begin{array}{l}\text { Unadj RR } 4.1 \text { (1.1-13.5) Adj. RR } \\
\text { NS. }\end{array}$ & $\begin{array}{l}\text { Adj RR } 2.0 \text { (0.6-6.1) for seropositivity at } \\
\text { enrolment; no data provided on seroincident } \\
\text { HSV-2 infection during study; potential bias } \\
\text { due to } 54 \% \text { loss to follow up. }\end{array}$ \\
\hline $\begin{array}{l}\text { Telzak et al, } 1993^{36} \\
\quad \text { (cohort) }\end{array}$ & $\begin{array}{l}758 \text { male heterosexual } \\
\text { STD clinic patients in } \\
\text { NYC without history of } \\
\text { IDU (14 SC). }\end{array}$ & $\begin{array}{l}\text { Clinical exam, Tzanck } \\
\text { smear ( } 95 \text { cases). }\end{array}$ & $\begin{array}{l}\text { Unadj RR } 1.1 \text { ( } \mathrm{p}>0.20) \\
\text { (compares herpes patients with } \\
\text { those with non-GUD STDs). }\end{array}$ & $\begin{array}{l}\text { Potential selection bias due to response rate } \\
\text { and recruitment strategy; potential } \\
\text { misclassification bias due to lack of HSV } \\
\text { culture or serology. }\end{array}$ \\
\hline \multicolumn{5}{|c|}{ Male to male transmission: } \\
\hline $\begin{array}{l}\text { Holmberg et al, } 1988^{41} \\
\text { (nested case } \\
\text { control) }\end{array}$ & $\begin{array}{l}104 \text { homosexual men in } \\
\text { San Francisco tested } \geqslant \\
\text { twice for HIV ( } 47 \text { SC; } 57 \\
\text { matched controls). }\end{array}$ & $\begin{array}{l}\text { HSV-2 antibody ( } 58 \\
\text { cases, including } 15 \\
\text { HSV-2 SC). }\end{array}$ & $\begin{array}{l}\text { HSV- } 2 \text { seropositivity in } 68 \% \text { HIV } \\
\text { SC } v 46 \% \text { controls, p<0.02; } \\
\text { HSV-2 SC in } 42 \% \text { HIV SC } v 14 \% \\
\text { controls, p<0.02. }\end{array}$ & $\begin{array}{l}\text { Associations significant after log linear } \\
\text { analysis of sexual behaviour }(\mathrm{p}=0.02) \text {; by } \\
\text { our calculation, unadj ORs } 2.5(1.1-6.2) \\
\text { and } 4.4(1.1-18.1) \text {, respectively. }\end{array}$ \\
\hline $\begin{array}{l}\text { Keet et al, } 1990^{42} \\
\text { (nested case } \\
\text { control) }\end{array}$ & $\begin{array}{l}107 \text { homosexual men in } \\
\text { Amsterdam ( } 53 \mathrm{SC} ; 54 \\
\text { matched controls). }\end{array}$ & $\begin{array}{l}\text { HSV-2 antibody ( } 53 \\
\text { cases, including } 6 \\
\text { HSV-2 SC). }\end{array}$ & $\begin{array}{l}\text { HSV-2 seropositivity in } 71 \% \mathrm{HIV} \\
\text { SC } v 38 \% \text { controls, } \mathrm{p}<0.05 \\
\text { (unadj OR } 4.0(1.7-9.8) \text { our } \\
\text { calculation); HSV-2 SC unadj OR } \\
2.2(0.4-12.1)\end{array}$ & $\begin{array}{l}\text { Authors conclude HSV-2 not a risk factor } \\
\text { despite results; number of sex partners } \\
\text { similar for cases/controls, no other control } \\
\text { for sexual behaviour; small numbers HSV-2 } \\
\text { SC. }\end{array}$ \\
\hline $\begin{array}{l}\text { Kingsley et al, } 1990^{43} \\
\text { (nested case } \\
\text { control) }\end{array}$ & $\begin{array}{l}98 \text { homosexual men in } \\
\text { Pittsburgh ( } 49 \text { SC; } 49 \\
\text { matched controls). }\end{array}$ & $\begin{array}{l}\text { HSV-2 antibody ( } 42 \\
\text { cases, including } 7 \\
\text { HSV-2 SC). }\end{array}$ & $\begin{array}{l}\text { HSV-2 seropositivity matched OR } \\
1.0(0.3-2.9) \text {. }\end{array}$ & $\begin{array}{l}\text { Cases and controls matched on number of } \\
\text { receptive anal intercourse partners; no other } \\
\text { adjustment for sexual behaviour. }\end{array}$ \\
\hline $\begin{array}{l}\text { Kuiken et al, } 1990^{44} \\
\text { (nested case } \\
\text { control) }\end{array}$ & $\begin{array}{l}235 \text { homosexual men in } \\
\text { Amsterdam ( } 84 \mathrm{SC} ; 151 \\
\text { matched controls). }\end{array}$ & $\begin{array}{l}\text { Self reported anogenital } \\
\text { herpes }(29 \text { cases). }\end{array}$ & Unadj OR 6.0 (2.34-13.7). & $\begin{array}{l}\text { OR significant after control for sexual } \\
\text { behaviour in log linear analysis. }\end{array}$ \\
\hline $\begin{array}{l}\text { Craib, et al, } 1995^{45} \\
\text { (nested case } \\
\text { control) }\end{array}$ & $\begin{array}{l}375 \text { homosexual men in } \\
\text { Vancouver (125 SC; } 250 \\
\text { controls). }\end{array}$ & $\begin{array}{l}\text { Self reported herpes }(76 \\
\text { cases). }\end{array}$ & Unadj OR 1.3 (0.8-2.2). & $\begin{array}{l}\text { Controls randomly selected; no attempt to } \\
\text { distinguish between primary and recurrent } \\
\text { genital HSV. }\end{array}$ \\
\hline
\end{tabular}

HIV infected, found that men who self reported GUD during the study were more than 13 times as likely to HIV seroconvert as those who did not report acquiring a genital ulcer. ${ }^{34}$ Although $H$ ducreyi, HSV-2 and syphilis serologies were obtained at enrolment, these markers of earlier infection were not associated with increased risk of incident HIV infection. The second study used a nested case-control design with careful adjustment for sexual behaviour and documented a two to threefold increased risk of HIV seroconversion among men with serological evidence of $H$ ducreyi or HSV-2 during the study period. ${ }^{35}$ Finally, in New York City, Telzak and colleagues ${ }^{36}$ studied 758 heterosexual men attending an STD clinic, of whom 14 HIV seroconverted. Chancroid was not as common in this study as in that by Cameron et al, but still accounted for $40 \%$ of GUD cases. People with chancroid were about three times as likely to HIV seroconvert as those who were not infected. Significant associations were not detected for syphilis or herpes, but misclassification bias may have occurred because almost $40 \%$ of chancroid cases were diagnosed on clinical criteria, and HSV cultures were not obtained.

Male to female transmission of HIV was studied among 124 female sex workers in Nairobi. After adjustment for sexual behaviour, those who developed GUD were three times as likely to HIV seroconvert as those who remained free of STDs (adjusted OR 3.3, 95\% CI $1.2-10.1) .^{37}$

Three articles examined HIV seroconversion for men and women in the same analysis. In a study of 256 serodiscordant European couples, HIV seroincidence was five times as high among non-index partners with self reported genital ulcers as among those without STDs. ${ }^{38}$
This result was statistically significant, although cases of GUD were too few to control for sexual behaviour. In a Baltimore STD clinic, among a retrospectively defined cohort of 147 clinic returnees tested at least twice for HIV, after adjustment for sexual behaviour, those with GUD were 11 times more likely to seroconvert than those without infection. ${ }^{39}$ Finally, among members of a large cohort of patients at two STD clinics in Pune, India, patients who had GUD on examination at their pre-seroconversion visit were more than four times as likely to seroconvert as those who did not. Furthermore, those who had GUD both before and after HIV seroconversion were more than eight times as likely to acquire HIV infection. It could not be determined whether the GUD present in the second visit (after seroconversion) was acquired at the same time as HIV, or at some other time, before or after seroconversion. ${ }^{40}$

\section{Genital herpes and HIV transmission}

Eight studies specifically address genital herpes as a factor in HIV seroconversion (table 4). Prospective data linking genital herpes with increased risk of HIV transmission are more equivocal than those for genital ulcers, particularly of bacterial aetiologies. This may be due, in part, to the fact that HSV-2 infection is a chronic disease manifested by recurrent anogenital ulcers, the frequency and severity of which decline in most patients over time. Therefore, while studies that use HSV-2 serology offer the advantage of a sensitive and specific ascertainment of HSV infection status, this measure may correlate poorly with recent genital ulceration which is the risk factor of importance. This means that studies of seroprevalent herpes, especially those in which 
serologies are obtained only at enrolment, may underestimate the impact of herpetic ulcers on HIV transmission. Despite these considerations and the fact that some of the studies are limited either by use of insensitive HSV detection methods or by failure to adjust for sexual behaviour, in aggregate, they suggest that genital herpes, particularly new infection resulting in HSV-2 seroconversion, may be associated with HIV acquisition.

Three studies address heterosexual transmission, in this case, female to male. In the two studies mentioned above that were conducted among Thai military conscripts, HSV-2 infection was detected serologically. After adjustment for sexual behaviour, in the nested case-control study, HSV-2 antibodies were three times as common among HIV seroconverters at the study visit before that at which HIV seroconversion was documented as among persistently HIV negative men at the analogous visit (adjusted OR 3.1, 95\% CI 1.2-7.9). ${ }^{35}$ However, in the cohort study in which HSV-2 antibodies were obtained only at enrolment, the fourfold increase in risk of HIV seroconversion that was observed in bivariate analysis fell to a twofold relative risk that failed to achieve statistical significance after adjustment for sexual behaviour (adjusted risk ratio (RR) $2.0,95 \%$ CI $0.6-6.1) .^{34}$ In the third study, there was no association of genital herpes with HIV acquisition, but ascertainment of HSV infection (by clinical examination and Tzanck preparation) was probably so insensitive that many HSV infections were missed. ${ }^{36}$

Three additional analyses which employed the more sensitive measure, HSV-2 antibody, were all conducted in homosexual men. Holmberg et al $^{41}$ studied HSV-2 antibody among 47 HIV seroconverting homosexual men and 57 matched controls in San Francisco, USA, and found that HSV-2 seropositive men were significantly more likely to acquire HIV than those without HSV-2 antibody. HSV-2 seroconversion resulted in an even greater increase in risk of HIV seroconversion. These associations persisted after potential confounding by sexual behaviour was addressed through log linear analysis. A similar nested case-control study of homosexual men in Amsterdam also documented increased risk of HIV acquisition associated with HSV-2 seropositivity. ${ }^{42}$ Only one of the three analyses, a nested case-control study of homosexual men in San Francisco matched on prior level of receptive anal intercourse ${ }^{43}$ failed to show an association between genital herpes and increased risk of $\mathrm{HIV}$ acquisition. Interestingly, of the two other studies which were conducted among homosexual men and relied exclusively upon self reported herpes as the outcome measure, one ${ }^{44}$ found a strong association, and the other ${ }^{45}$ was unable to document any relation.

\section{Syphilis and HIV transmission}

Nine studies examined the role of syphilis in HIV acquisition (table 5). The majority are limited either by small numbers of syphilis cases or by reliance on self reported history to ascertain a syphilis diagnosis. However, four of the six studies with 10 or more syphilis cases revealed a significant association between syphilis and increased risk of HIV transmission on multivariate analysis, with risk estimates that range from 2.3 to $8.6 .^{4446-48}$ The other two studies, one conducted using clinical and laboratory indicators of syphilis among heterosexual men in New York ${ }^{36}$ and the other conducted using self reported syphilis among homosexual men in Vancouver, ${ }^{45}$ reported univariate risk estimates of 3.4 and 3.8, respectively, but these associations did not remain significant after adjustment for sexual behaviour.

Of the six studies with sufficient numbers of syphilis cases to permit multivariate analysis, two were conducted among heterosexuals, ${ }^{36} 46$ three among homosexual men, ${ }^{45} 47$ and one did not restrict the analysis with respect to route of sexual transmission. ${ }^{48}$ In Miami, investigators found that among a retrospective cohort of 106 women who were HIV negative during antenatal testing on average 3.8 years earlier, those who became HIV infected were more than eight times as likely to have serological evidence of syphilis documented in their medical records since their pregnancies than women who remained free of HIV infection (adjusted OR 8.6, 95\% CI 1.0-84). ${ }^{46}$ In contrast, the New York study of heterosexual male STD clinic patients mentioned above did not demonstrate a significant association between syphilis and HIV acquisition on multivariate analysis. ${ }^{36}$ This may have reflected, in part, the fact that syphilis patients were compared with non-GUD STD clinic patients rather than with men who did not receive an STD diagnosis. All three studies that were conducted among homosexual men relied on self reported history of syphilis, which is neither sensitive nor specific for detection of the disease. Nevertheless, two of these studies reported unadjusted odds ratios of 2.3 and 3.5 which remained significant in multivariate analysis. $^{44} 47$

Strong evidence that syphilis facilitates HIV transmission is also provided by the remaining study of over 5100 patients who were tested twice for HIV at four Miami STD clinics. ${ }^{48}$ Patients who were diagnosed with syphilis between the two HIV tests were almost three times as likely to HIV seroconvert as those who were diagnosed with syphilis before the first HIV test. These patients, in turn, were almost one and a half times as likely to seroconvert as those in whom syphilis was never diagnosed. The first of these analyses included only patients who had had syphilis at some point, and who shared behavioural risk factors for syphilis. Assuming that these risk factors remained stable over time, the ratio of HIV incidences in the two groups represents a measure of the additional risk of acquiring HIV incurred by having syphilis during an HIV exposure. Uniquely, this study also adjusted for the higher prevalence in Miami of HIV infection among syphilis patients than among patients with other STDs. This factor contributes importantly to the true population attrib- 
Table 5 Prospective studies of syphilis and HIV seroconversion

\begin{tabular}{|c|c|c|c|c|}
\hline Author, year (design) & $\begin{array}{l}\text { Study population (number of HIV } \\
\text { seroconverters) }\end{array}$ & $\begin{array}{l}\text { Ascertainment of syphilis } \\
\text { (number of cases) }\end{array}$ & Risk estimates (95\% CI) & Comments/study limitations \\
\hline \multicolumn{5}{|c|}{ Female to male transmission: } \\
\hline $\begin{array}{l}\text { Nelson et al, } 1998^{35} \\
\text { (nested case } \\
\text { control) }\end{array}$ & $\begin{array}{l}169 \text { male Thai military } \\
\text { conscripts ( } 45 \text { SC; } 124 \text { controls). }\end{array}$ & VDRL/TPHA (5 cases). & Unadj OR 1.5 (0.02-27.6). & Low numbers of syphilis cases. \\
\hline $\begin{array}{l}\text { Nopkesorn et al, } \\
1998^{34} \text { (cohort) }\end{array}$ & $\begin{array}{l}1036 \text { male Thai military } \\
\text { conscripts ( } 14 \text { SC). }\end{array}$ & $\begin{array}{l}\text { RPR/MHATP ( } 34 \text { prevalent } \\
\text { plus } 7 \text { incident cases). }\end{array}$ & $\begin{array}{l}\text { Unadj RR } 2.0(0.1-14.3) \\
\text { for seropositivity at } \\
\text { enrolment. }\end{array}$ & $\begin{array}{l}\text { Too few incident syphilis cases to permit } \\
\text { analysis; potential bias due to } 54 \% \text { loss } \\
\text { to follow up. }\end{array}$ \\
\hline $\begin{array}{l}\text { Telzak et al, } 1993^{36} \\
\quad \text { (cohort) }\end{array}$ & $\begin{array}{l}758 \text { male heterosexual STD } \\
\text { clinic patients in NYC without } \\
\text { history of IDU ( } 14 \text { SC). }\end{array}$ & $\begin{array}{l}\text { Clinical exam, RPR/MHATP, } \\
\text { dark field, history of exposure } \\
\text { (123 cases). }\end{array}$ & $\begin{array}{l}\text { Unadj RR } 3.4(p=0.09) \\
\text { Adj OR not significant. }\end{array}$ & $\begin{array}{l}\text { Potential selection bias due to response } \\
\text { rate and recruitment strategy; compares } \\
\text { patients with syphilis with those with } \\
\text { non-GUD STDs. }\end{array}$ \\
\hline \multicolumn{5}{|c|}{ Male to female transmission: } \\
\hline $\begin{array}{l}\text { Dominguez et al, } \\
1996^{46} \text { (nested case } \\
\text { control in } \\
\text { retrospective } \\
\text { cohort) }\end{array}$ & $\begin{array}{l}106 \text { women in Miami from } \\
\text { random sample of } 407 \text { testing } \\
\text { HIV negative on average } 3.8 \\
\text { years earlier during antenatal care } \\
\text { (10 SC; } 96 \text { controls). }\end{array}$ & $\begin{array}{l}\text { Syphilis serology from } \\
\text { medical records ( } 11 \text { cases). }\end{array}$ & Adj OR $8.6(1.0-84)$. & $\begin{array}{l}\text { Adjusted for condom use, number of } \\
\text { lifetime sex partners, and sex partner at } \\
\text { risk for HIV. }\end{array}$ \\
\hline $\begin{array}{l}\text { Laga et al, } 1993^{51} \\
\text { (nested case } \\
\text { control) }\end{array}$ & $\begin{array}{l}431 \text { FSWs in Kinshasa, Zaire ( } 68 \\
\text { SC; } 126 \text { matched controls). }\end{array}$ & RPR/TPHA (9 cases). & Unadj OR 3.4 (0.7-17.6). & $\begin{array}{l}\text { Few syphilis cases; syphilis not included } \\
\text { in multivariate analyses. }\end{array}$ \\
\hline \multicolumn{5}{|c|}{ Male to male transmission: } \\
\hline $\begin{array}{l}\text { Craib et al, } 1995^{45} \\
\text { (nested case } \\
\text { control) }\end{array}$ & $\begin{array}{l}375 \text { homosexual men in } \\
\text { Vancouver (125 SC; } 250 \\
\text { controls). }\end{array}$ & $\begin{array}{l}\text { Self reported syphilis }(14 \\
\text { cases). }\end{array}$ & Unadj OR 3.8 (1.3-10.8). & $\begin{array}{l}\text { Controls randomly selected; OR not } \\
\text { significant in multivariate model. }\end{array}$ \\
\hline $\begin{array}{l}\text { Darrow et al, } 1987^{47} \\
\quad \text { (cohort) }\end{array}$ & $\begin{array}{l}359 \text { homosexual men in San } \\
\text { Francisco }(240 \text { SC). }\end{array}$ & $\begin{array}{l}\text { Self reported treatment for } \\
\text { syphilis (101 cases). }\end{array}$ & Unadj OR 3.5 (1.9-6.2). & $\begin{array}{l}\text { OR significant after control for sexual } \\
\text { behaviour in multivariate analysis. }\end{array}$ \\
\hline $\begin{array}{l}\text { Kuiken et al, }{ }^{44} 1990 \\
\text { (nested case } \\
\text { control) }\end{array}$ & $\begin{array}{l}235 \text { homosexual men in } \\
\text { Amsterdam ( } 84 \text { SC; } 151 \\
\text { matched controls). }\end{array}$ & $\begin{array}{l}\text { Self reported syphilis ( } 98 \\
\text { cases). }\end{array}$ & Unadj OR 2.3 (1.3-4.1). & $\begin{array}{l}\text { OR significant after control for sexual } \\
\text { behaviour in log linear analysis. }\end{array}$ \\
\hline \multicolumn{5}{|c|}{ All routes of transmission: } \\
\hline $\begin{array}{l}\text { Otten et al, } 1994^{48} \\
\text { (retrospective } \\
\text { cohort) }\end{array}$ & $\begin{array}{l}5164 \text { STD clinic patients in } \\
\text { Miami ( } 208 \text { SC). }\end{array}$ & $\begin{array}{l}\text { Syphilis serology from } \\
\text { medical records (1913 P\&S } \\
\text { or latent cases). }\end{array}$ & $\begin{array}{l}\text { "Quasi-adjusted" incidence } \\
\text { ratio } 2.9(1.9-4.3) \text {-for } \\
\text { those diagnosed with } \\
\text { syphilis between HIV tests } \\
\text { compared with that of } \\
\text { those diagnosed before first } \\
\text { HIV test. }\end{array}$ & $\begin{array}{l}\text { Incidence ratio for syphilis diagnosis } \\
\text { before first HIV test } v \text { no syphilis } \\
\text { diagnosis } 1.4(1.0-1.9) \text {. }\end{array}$ \\
\hline
\end{tabular}

$\mathrm{SC}=$ seroconverters; IDU=injecting drug use; VDRL=Venereal Diseases Research Laboratory; TPHA=Treponema pallidum haemagglutination assay; RPR=rapid plasma reagin; $\mathrm{MHATP}=$ microhaemagglutination assay for antibodies to Treponema pallidum; $\mathrm{P} \& \mathrm{~S}=$ primary and secondary syphilis; $\mathrm{OR}=\mathrm{odds}$ ratio; $\mathrm{RR}=$ risk ratio; GUD=genital ulcer disease.

utable risk of syphilis, but it may upwardly bias the estimate of the facilitating effect of syphilis on HIV transmission.

\section{Non-ulcerative STDs and HIV transmission}

Non-ulcerative STDs also appear to play a role in facilitating HIV transmission, with risk estimates from 13 prospective studies that are largely similar to those for ulcerative STDs (table 6). However, the relative importance of ulcerative and non-ulcerative STDs in HIV transmission is probably complex. If the effect of non-ulcerative STDs on HIV acquisition is, indeed, in the range indicated by these studies, the ultimate impact of non-ulcerative STDs on the HIV epidemic could potentially be much greater than that of GUD because nonulcerative STDs are far more common than genital ulcers in most populations. On the other hand, the impact of non-ulcerative STDs may be more limited than that of GUD for two reasons. Firstly, HIV infection does not alter the natural history or response to therapy of non-ulcerative STDs to the same extent that it does for GUD. ${ }^{5}$ Thus, the "epidemiological synergy" that fuels the mutually reinforcing spiral of infection observed with ulcerative STDs and HIV infection is far more modest or absent with non-ulcerative STDs. Secondly, the available data suggest (tables 3-6) and it is biologically plausible that, while genital ulcers increase HIV risk bidirectionally for both receptive and insertive sex partners (for example, among heterosexuals for both female to male and male to female transmission), nonulcerative STDs may increase risk primarily for the receptive partner. Almost all of the studies specifically supporting a role for gonorrhoea, chlamydial infection, or trichomoniasis document an increased risk of male to female HIV transmission (table 6). The two exceptions are a study of STD clinic patients in which the increased HIV risk was carried by those individuals who experienced male to female HIV transmission, ${ }^{39}$ and a study of homosexual men in which rectal gonorrhoea, but not urethral or pharyngeal infection, was associated with HIV acquisition in multivariate analysis. ${ }^{45}$ Mathematical models may be helpful in understanding the dynamic interplay of these factors in a range of settings.

\section{Gonorrhoe and HIV transmission}

Eleven of the 13 prospective studies of non-ulcerative STDs specifically address gonococcal infection. Of these, nine showed a statistically significant association of gonorrhoea with HIV seroconversion, although in two of the studies ${ }^{47}{ }^{49}$ the association did not remain significant in multivariate analysis and in on $\mathrm{e}^{50}$ no attempt was made to adjust for sexual behaviour (table 6). Risk estimates in the six remaining studies ${ }^{39}{ }^{45} 51-53$ ranged from 3.2 to 
Table 6 Prospective studies of non-ulcerative STDs and HIV seroconversion

\begin{tabular}{|c|c|c|c|c|}
\hline $\begin{array}{l}\text { Author, year } \\
\text { (design) }\end{array}$ & $\begin{array}{l}\text { Study population (number of } \\
\text { HIV seroconverters) }\end{array}$ & $\begin{array}{l}\text { Ascertainment of non-ulcerative } \\
\text { STDs (number of cases) }\end{array}$ & Risk estimates (95\% CI) & Comments/study limitations \\
\hline \multicolumn{5}{|c|}{ Female to male transmission: } \\
\hline $\begin{array}{l}\text { Nopkesorn et } \\
\text { al, } 1998^{34} \\
\text { (Cohort) }\end{array}$ & $\begin{array}{l}1036 \text { male Thai military } \\
\text { conscripts ( } 14 \text { SC). }\end{array}$ & $\begin{array}{l}\text { Self reported urethritis during } \\
\text { study ( } 224.7 \text { person years). }\end{array}$ & $\begin{array}{l}\text { Adj RR for incident urethritis } 6.0 \\
(1.8-20.9) \text {. }\end{array}$ & $\begin{array}{l}\text { Adjusted for FSW contact and receptive } \\
\text { anal intercourse, but no objective STD } \\
\text { diagnosis; potential bias due to } 54 \% \text { loss } \\
\text { to follow up. }\end{array}$ \\
\hline
\end{tabular}

\begin{tabular}{|c|c|c|c|}
\hline \multicolumn{4}{|c|}{ Male to female transmission: } \\
\hline $\begin{array}{l}\text { Dominguez et } \\
\text { al, } 1996^{46} \\
\text { (nested case } \\
\text { control in } \\
\text { retrospective } \\
\text { cohort) }\end{array}$ & $\begin{array}{l}106 \text { women in Miami from } \\
\text { random sample of } 407 \text { testing } \\
\text { HIV negative on average } 3.8 \\
\text { years earlier during antenatal } \\
\text { care ( } 10 \text { SC; } 96 \text { controls). }\end{array}$ & $\begin{array}{l}\text { From medical records, GC } \\
\text { culture ( } 8 \text { cases); CT EIA ( } 16 \\
\text { cases); trich wet mount ( } 11 \\
\text { cases). }\end{array}$ & $\begin{array}{l}\text { Adj ORs: GC } 23.5(2.3-383) \mathrm{C} \\
10.7(1.8-84) \text { Trich } 4.7 \\
(0.5-41.1) .\end{array}$ \\
\hline $\begin{array}{l}\text { Kapiga et al, } \\
1998^{52} \\
\text { (cohort) }\end{array}$ & $\begin{array}{l}2471 \text { women at } 3 \text { FP clinics in } \\
\text { Dar es Salaam, Tanzania ( } 75 \\
\text { SC). }\end{array}$ & $\begin{array}{l}\text { GC culture ( } 42 \text { cases); trich } \\
\text { wet mount ( } 164 \text { cases). }\end{array}$ & $\begin{array}{l}\text { Adj RR: GC } 3.8 \text { (1.7-8.5); trich } \\
\text { NS. }\end{array}$ \\
\hline $\begin{array}{l}\text { Kilmarx et al } \\
1997^{49} \\
\text { (cohort) }\end{array}$ & $\begin{array}{l}285 \text { FSWs in Chiang Rai, } \\
\text { Thailand ( } 30 \text { SC). }\end{array}$ & $\begin{array}{l}\text { CT and GC nucleic acid } \\
\text { hybridisation; trich wet mount } \\
\text { (number of cases NA). }\end{array}$ & $\begin{array}{l}\text { Adj RRs: CT } 3.4 \text { (1.4-7.8); GC } \\
\text { and trich NS. }\end{array}$ \\
\hline
\end{tabular}

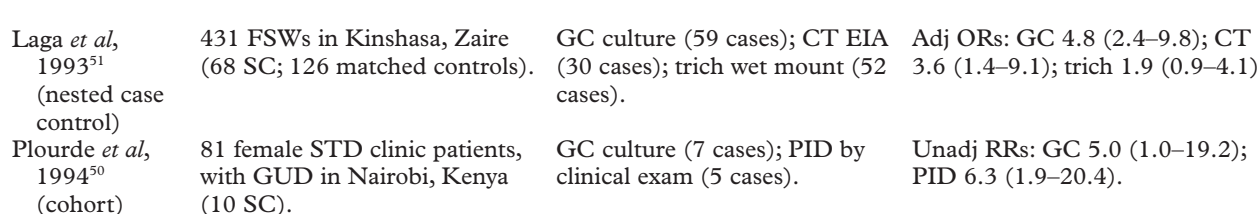

Plummer et al, 124 FSWs in Nairobi, Kenya $1991^{37}$ (cohort) (83 SC).

\begin{tabular}{|c|c|}
\hline $\begin{array}{c}\text { Taha et al, } \\
1998^{53}\end{array}$ & $\begin{array}{l}1196 \text { pregnant women in } \\
\text { Blantyre, Malawi ( } 27 \text { SC). }\end{array}$ \\
\hline $\begin{array}{l}\text { Weir et al, } \\
1994^{54} \\
\text { (nested case } \\
\text { control) }\end{array}$ & $\begin{array}{l}273 \text { FSWs in Yaounde, } \\
\text { Cameroon (17 SC; } 68 \\
\text { controls). }\end{array}$ \\
\hline
\end{tabular}

CT and GC culture (CT 38 cases; GC mean 0.2 (SD 0.3) cases/month).

GC culture (34 cases); trich wet mount ( 275 cases); BV by clinical criteria (274 cases) GC culture (32 cases).

Adj ORs: CT 2.7 (0.9-7.8); GC NS.

Adj ORs: GC 4.3 (1.2-15.7); BV $3.7(\mathrm{p}=0.04$, test for trend with increasing severity); trich NS. OR $1.4(0.4-4.9)$.
Adjusted for condom use, number of lifetime sex partners, and sex partner at risk for HIV; unadj OR for trich 3.7 (1.1-12).

STD tests obtained at baseline only; potential bias due to $45 \%$ loss to follow up. "Dose response:" CT unadj RR 3.6 (1.4-9.7) w/1 pos test, $10.4(4.3-25.2)$ w/ 122 pos tests; GC unadj RR 3.5 (1.4-9.0) and 6.2 (2.0-19.3), respectively. Trich unadj RR 2.0 (0.3-14.7). See also Laga et al, $1994^{58}$ for related analysis.

Potential bias due to $40 \%$ loss to follow up and lower STD rates in 81 subjects than in 53 LTFU; small numbers of HIV and STD cases; no adjustment for sexual behaviour.

Potential bias due to $37 \%$ loss to follow up; GC relatively rare among subjects. Unadj OR: GC $2.2(0.7-6.6)$; adj For adj $\mathrm{OR}$, condom/N 9 use from coital

\section{Male to male transmission:}

Craib et al, $\quad 375$ homosexual men in $1995^{45} \quad$ Vancouver (125 SC; 250 (nested case controls) control)

Darrow et al, $1987^{47}$ (cohort) Francisco (240 SC).
359 homosexual men in San

All routes of transmission: asslet $1994^{39}$ (nested case control)

Mehendale et 851 STD clinic patients in al, $1995^{40} \quad$ Pune, India (62 SC). (cohort)

\author{
Self reported GC (27 urethral, \\ 7 pharyngeal, and 16 rectal \\ cases). \\ Self reported treatment for GC \\ (266 cases).
}

GC unadj ORs: urethral 2.8 (1.3-5.8), pharyngeal 5.2 (1.2-23.0), rectal $4.7(1.8-12.8)$; rectal GC adj OR $3.2(\mathrm{p}=0.04)$. Unadj OR: GC 3.0 (1.9-4.9). logs as continuous variable, data reliability unclear.

Urethral and pharyngeal GC NS on multivariate analysis.

OR not significant in multivariate analysis; no subanalysis of rectal GC.

$\mathrm{SC}=$ seroconverters; $\mathrm{GUD}=$ genital ulcer disease; $\mathrm{FSW}=$ female sex workers; $\mathrm{FP}=$ family planning; $\mathrm{CT}=$ Chlamydia trachomatis; EIA=enzyme immunoassay; $\mathrm{GC}=$ gonorrhoea; $\mathrm{BV}=$ bacterial vaginosis; $\mathrm{PID}=$ pelvic inflammatory disease; $\mathrm{GS}=\mathrm{Gram}$ stain; $\mathrm{RR}=$ risk ratio; $\mathrm{OR}=\mathrm{odds}$ ratio; $\mathrm{NS}=$ not significant.

5.1 with the exception of one study which reported an adjusted odds ratio of $23.5 .{ }^{46}$

The majority of the studies of gonorrhoea examine male to female HIV transmission. Three relatively large studies of family planning clinic clients in Dar es Salaam, antenatal clinic patients in Blantyre, and female sex workers in Kinshasa, ${ }^{51-53}$ documented adjusted risk estimates of $4.2,4.3$, and 4.8 , respectively, while a smaller study of women identified through prenatal care in Florida found an adjusted odds ratio of 23.5 with a wide confidence interval. ${ }^{46}$ Another smaller study of female STD clinic patients in Nairobi found an unadjusted relative risk of $5.0 .^{50}$ However, three additional studies of male to female gonorrhoea transmission among female sex workers in Chiang Rai, Cameroon, and Nairobi failed to show a significant association with HIV acquisition in multivariate analysis. ${ }^{37} 4954$ The smaller sample sizes with more limited numbers of HIV seroconversions or relatively low incidences of gonorrhoea in two of these studies $^{37}{ }^{54}$ may, in part, explain these divergent results.

One study addresses gonorrhoea and HIV transmission among both men and women. In this study, conducted among STD clinic attenders in Baltimore ${ }^{39}$ gonorrhoea was associated with a fivefold increase in risk of HIV seroconversion. As mentioned above, unpublished subgroup analyses suggested that the increased risk here, too, was carried primarily among those individuals experiencing male to female transmission (unadjusted OR 7.2 (CI 0.8-64) for male to female transmission, and 
Genital ulcers Syphilis Gonorrhoea Chlamydia Trichomoniasis

Male clients CSWs in Nairobi, Kenya (Cameron et al, 198933)

CSWs in Nairobi, Kenya (Plummer et al, 1991 ${ }^{37}$ )

CSWs in Kinshasa (Laga et al, $1993^{51}$ )

STD clinic attenders in India (Mehendale et al, $1995^{40}$ )

STD clinic patients in Baltimore, MD, USA (Kassler et al, 1994 ${ }^{39}$ )

STD clinic patients in Miami, FL, USA (Otten et al, 1994 ${ }^{48}$ )

$69 \%$

$44 \%$

$54 \%$

$7 \%$

Included in this table were studies which presented an odds ratio for the given STD which was adjusted for behaviour, and which supplied sufficient information for the calculation of population attributable risk (PAR).

PAR was calculated from the adjusted odds ratio and the proportion of cases (seroconverters) who had the exposure (STD) of interest. $\left(\mathrm{PAR}=\left(1-1 /\right.\right.$ adj OR) (prevalence of STD among HIV seroconverters) ${ }^{44}$

^Indicates that the PAR was presented in the article itself, and agreed with our calculations; all other figures are from our calculations.

2.0 (CI, 0.8-4.9) for female to male transmission (William Kassler, personal communication)).

Unfortunately, there are few prospective data on male to male transmission of gonorrhoea. The two published studies conducted among homosexual men both relied upon self reports of gonorrhoea and found that gonococcal infection was associated with HIV seroconversion in univariate analysis. ${ }^{45}$ On multivariate analysis, one study found that rectal gonorrhoea increased risk of HIV acquisition threefold, while urethral and pharyngeal infection were no longer associated with increased risk. ${ }^{45}$ The other study, which did not include analyses by anatomical site of gonococcal infection, no longer revealed a significant association. $^{47}$

Other non-ulcerative STDs and HIV transmission Other non-ulcerative STDs such as chlamydial infection and trichomoniasis are also linked to HIV seroconversion, although fewer studies have addressed these diseases, perhaps because accurate detection of these organisms is more technically difficult than is detection of gonorrhoea (table 6). In the two studies from Africa in which chlamydia was diagnosed in women by enzyme immunoassay (EIA) ${ }^{51}$ and by culture, ${ }^{37}$ adjusted odds ratios were 3.6 and 2.7, respectively. A third study conducted among women in Miami using EIA reported and adjusted odds ratio of 10.7 with wide confidence intervals. ${ }^{46}$ Trichomonal infection in women was found to be associated with HIV acquisition (with borderline statistical significance) in Kinshasa, ${ }^{51}$ but not in Blantyre or Baltimore. ${ }^{39} 53$ One group at a Nairobi STD clinic found that clinically diagnosed pelvic inflammatory disease (PID) was strongly associated with HIV acquisition, with unadjusted odds ratio of $6.3 .^{50}$ Although PID itself would be unlikely to increase HIV transmission risk, it may be assumed that PID in this study is a proxy for previous infection with gonorrhoea, chlamydia, or other pathogens. Finally, two prospective studies considered the role of urethritis or cervicitis in HIV transmission. In a study of both men and women at an STD clinic in India, Mehendale and colleagues found an association between HIV acquisition and urethritis or cervicitis, with an adjusted odds ratio of 3.0 (95\% CI $1.4-6.5) .^{40}$ Self reported urethritis was also strongly associated with HIV acquisition among male Thai military conscripts (adjusted RR 6.0, 95\% CI 1.8-20.9)..$^{34}$ Recent evidence suggests that bacterial vagino- sis, which is not an STD, but which causes abnormal vaginal discharge, may also increase risk of HIV infection, although the biological mechanism responsible for this finding is not yet clear. ${ }^{525}$

POPULATION ATTRIBUTABLE RISK OF STDS FOR HIV TRANSMISSION AND MATHEMATICAL MODELS A number of the HIV seroconversion studies discussed above provide sufficient information to calculate, for a given study, the population attributable risk (PAR) of various sexually transmitted diseases for HIV acquisition (table 7 ). The PAR is a measure of the proportion of cases of disease in a population that could, theoretically, be averted by removing a given exposure if an intervention were able to achieve complete coverage and optimal effectiveness. It takes into account not only the magnitude of the risk associated with the exposure, but also the prevalence of the exposure in the population of interest. ${ }^{56}$ Vittinghoff and Padian ${ }^{57}$ discuss the strengths and limitations of the PAR as applied to STDs. It should be noted that in the specific case of studies of HIV seroconversion related to other STDs, the PAR may substantially underestimate potentially avertable cases because it reflects only the effect of STDs on HIV susceptibility and does not capture the effect on HIV infectiousness.

PARs for GUD were generally higher than those for non-ulcerative STDs. It is interesting to note that the PARs of GUD in studies conducted in the developing world were higher $(44 \%-69 \%)$ than in those conducted in the United States $(7 \%-18 \%)$, largely reflecting the lower prevalence of these diseases in the United States than in developing countries. This observation underscores the fact that a given PAR applies specifically to the population studied at a given phase of an epidemic, and may not easily translate to other populations. In the United States, for example, the STD attributable HIV transmission risk could feasibly be increasing, as heterosexual modes of transmission assume a larger role in HIV epidemiology.

Mathematical models of the impact of other STDs on HIV transmission suggest that the effect of these diseases may be much greater than is suggested by studies using standard epidemiological analytical approaches to estimate effects at a given time. Dynamic models may more accurately reflect the explosive way in which the effect of STDs is multiplied through ongoing HIV transmission. ${ }^{58-61}$ Some models suggest that STD incidence and preva- 
lence may be critical to sustaining heterosexual transmission of HIV infection. Modelling also suggests that the effectiveness and cost effectiveness of STD treatment in HIV prevention may be greater during earlier stages of an HIV epidemic, before HIV infection becomes widely distributed ${ }^{62-65}$ and the relative importance of incurable viral STDs, like herpes, begins to increase. Finally, mathematical models highlight the importance of providing STD treatment to those who are most likely to transmit infection to others in order to maximise the population level impact and cost effectiveness of STD control interventions. ${ }^{66}$

\section{INTERVENTION TRIALS}

Although very valuable, the observational studies discussed above are inherently subject to a number of potential limitations, and they cannot directly measure the effect of STD control on HIV incidence in the larger population. ${ }^{5867-70}$ Quasi-experimental intervention projects conducted among female sex workers (FSWs) in Zaire, Kenya, and Bolivia have shown that routine STD clinical services and condom promotion may be associated with dramatic reductions in HIV incidence or prevention of epidemic increases in HIV infection in high risk populations. ${ }^{71-73}$ In the Zairian study, for example, HIV incidence rose from 2.7 per 100 women years among FSWs who attended more than $90 \%$ of their monthly clinic visits to $7.1,20.3$, and 44.1 per 100 women years among FSWs who attended $76-90 \%, 50-75 \%$, and less than $50 \%$ of their scheduled visits, respectively. ${ }^{71}$ However, without randomised, controlled designs, these studies, too, have limited ability to demonstrate causal relations and estimate the magnitude of the intervention effect.

Two community level randomised, controlled intervention trials have been conducted in Africa, the first in the Mwanza region of Tanzania, and the second in the Rakai district of Uganda. Both of these trials attempted to quantitate the effect of STD treatment on HIV incidence by randomising entire communities to receive either some form of augmented STD treatment or the local standard of STD care. A third community level randomised, controlled trial is currently ongoing in the Masaka district of Uganda. Its three arms compare the effect on HIV incidence of (i) behavioural intervention to promote safer sex, and (ii) improved STD management plus the behavioural intervention, with a comparison group receiving community development activities.

Mwanza trial: improved clinic based treatment of symptomatic STDs to reduce HIV incidence Investigators in Mwanza, Tanzania, provided continuous access to improved treatment for symptomatic STDs through existing primary healthcare clinics in six rural communities. ${ }^{74}$ The intervention included training of staff from health centres and dispensaries in STD diagnosis and treatment using syndromic algorithms, assuring a regular supply of drugs, implementing routine supervisory visits to health facilities, and establishing an STD reference clinic and laboratory. In addition, health educators in the intervention areas visited villages to provide information on STDs, focusing on the availability of effective treatment and encouraging prompt treatment of symptomatic STDs. For 24 months the six matched, comparison communities received STD clinical services that were unchanged from those that had existed previously, at which time the intervention was also implemented in the comparison communities.

After 24 months, this intervention resulted in a $38 \%$ reduction in HIV incidence in the intervention communities compared with the control communities. ${ }^{74}$ In each of the six communities that received this relatively modest intervention, HIV incidence was substantially lower than in the corresponding matched comparison community (range $12 \%-65 \%$ ). Importantly, the greatest impact of the intervention was in women aged 15-24 years, and men aged 25-34, groups in which the HIV incidence was highest in the comparison communities. Significant reductions were documented in the prevalence of serologically diagnosed syphilis ( $R P R ~ \geqslant 1: 8$; adjusted RR $0.71,95 \%$ CI 0.54-0.93) and borderline significant reductions were observed in the prevalence of new cases of syphilis ( $R P R \geqslant 1: 8$; adjusted RR 0.62 , $95 \%$ CI $0.38-1.02$ ) and of symptomatic urethritis in the previous year (adjusted RR $0.51,95 \%$ CI $0.25-1.03){ }^{75}$ These results were not associated with changes in sexual behaviour or condom use that might confound the association between improved STD treatment and HIV transmission.

Economic analysis of the STD treatment intervention in Mwanza showed that it was cost effective in preventing HIV infection at US $\$ 218$ per HIV infection averted and $\$ 10$ per disability adjusted life year (DALY) saved. ${ }^{76}$ These estimates compare favourably with other effective and widely implemented public health interventions such as childhood immunisation (estimated cost effectiveness \$12-17 per DALY saved). ${ }^{76}$

Rakai trial: intermittent home based mass treatment of STDs to reduce HIV incidence In Rakai, Uganda, investigators tested another approach to STD treatment for HIV prevention. ${ }^{77}$ In the intervention communities, which were grouped into five clusters of four to seven villages reflecting social and sexual networks, directly observed mass treatment for curable STDs was provided irrespective of symptom status at 10 month intervals in subjects' homes using single dose antibiotics (oral azithromycin, ciprofloxacin, and metronidazole and intramuscular benzathine penicillin for serological evidence of syphilis). In the five control community clusters, home based mass treatment was provided in a single blinded fashion using an antihelminth (mebendazole), iron folate, and low dose multivitamins. Symptomatic subjects who were encountered in control communities during mass treatment rounds were referred for STD care to the project's mobile clinics which were available only during these periods. All study subjects 
were offered HIV prevention education and serological counselling, condoms, and free general health care at the project's mobile clinics.

After three mass treatment rounds that spanned 20 months and included two follow up intervals, HIV incidence was similar in the intervention and control communities overall (adjusted rate ratio $0.97,95 \%$ CI $0.81-1.16$ ) and in each of the randomised pairs. ${ }^{77}$ By the third round, significant reductions were observed in the prevalence of serologically diagnosed syphilis (adjusted prevalence ratio $0.80,95 \%$ CI $0.71-0.89)$ and trichomoniasis (adjusted prevalence ratio $0.59,95 \%$ CI 0.38 $0.91)$, and in the incidence of trichomoniasis (adjusted RR 0.52, 95\% CI 0.35-0.79), but not of syphilis. Borderline significant reductions in bacterial vaginosis (BV) prevalence also occurred (adjusted prevalence ratio 0.87, 95\% CI 0.74-1.02).

\section{Mwanza and Rakai results: consistent or} contradictory?

Why did STD treatment dramatically reduce HIV incidence in Mwanza, but not in Rakai? Although superficially the results of these two landmark, community level, randomised, controlled trials may appear contradictory, in fact, the two studies tested different STD treatment interventions using different measurement approaches in populations with different HIV and STD epidemiology. The findings are, not surprisingly, different, but consistent and complementary.

Among the multiple factors that may have contributed to the divergent results of the two trials at least four explanations probably combined to produce the dramatic reduction in HIV incidence in Mwanza and the equally stunning absence of effect on HIV incidence in Rakai.

Firstly, in light of the frequency with which most individuals have sex, it is logical that continuous access to improved STD treatment services would be more effective than intermittent mass treatment administered as infrequently as every 10 months. For example, in Rakai, individuals who became infected within days after a mass treatment round had few STD treatment options for the next 10 months other than the inadequate clinic care that had existed before the trial.

Secondly, symptomatic STDs may be more important than asymptomatic infections in facilitating HIV transmission, while asymptomatic STDs may be more central to ongoing spread of STDs and development of sequelae. Biologically, this is because symptomatic STDs are more likely than asymptomatic cases to be associated with fulminant inflammatory responses or larger ulcers, factors that facilitate HIV transmission. Asymptomatic STDs, on the other hand, are more likely to persist untreated and, as a result, spread to others or progress to complications in the original patient. Symptomatic STDs also often reflect recently acquired or incident infections and, therefore, recent risky sexual behaviours. Thus, focusing on symptomatic STDs may be a very effective way to target STD treatment interventions.

Thirdly, as discussed above, STDs may play a greater role in HIV transmission in earlier than in later phases of an HIV epidemic. As HIV epidemics mature and infection becomes widely disseminated in the population, exposure of the limited number of individuals who remain biologically and behaviourally susceptible becomes increasingly independent of cofactors such as STDs. Furthermore, the relative contribution of curable STDs may decline in late HIV epidemics as viral STDs like genital herpes become common. The Rakai district was experiencing a far more advanced HIV epidemic during that study than the Mwanza region was during its trial, with baseline HIV prevalence of $16 \%$ and $4 \%$, respectively. ${ }^{74} 77$

Finally, local STD incidence, prevalence, and aetiological spectrum are critical determinants of the impact of any STD treatment intervention on HIV transmission. The STD detection methods used in the Rakai study were much more sophisticated and extensive than those used in the Mwanza trial, making direct comparisons difficult. However, the available data suggest that while syphilis prevalence rates were probably comparable in the two study populations, gonorrhoea and chlamydia prevalence may have been slightly higher in Mwanza and the proportion of genital ulcers due to HSV-2 was probably substantially higher in Rakai.

\section{Implications for policy and practice}

The extensive observational and growing intervention trial data leave little doubt that other STDs facilitate HIV transmission through direct, biological mechanisms. ${ }^{78} 79$ The question is no longer whether STD detection and treatment should be an essential component of HIV prevention programmes, but rather how this component should be implemented to have maximal impact on HIV incidence in specific populations. ${ }^{80}$

The intervention studies currently suggest that intermittent mass treatment, alone, delivered to the general population is not an effective approach to STD control for HIV prevention, particularly in a late HIV epidemic with relatively low rates of curable STDs. However, targeted mass treatment (for example, among high frequency transmitters or others with high STD incidence or prevalence) at relatively short intervals deserves additional examination in combination with establishment of high quality, continuous STD treatment services to achieve a rapid, initial reduction in STD rates as a "lead in" to more comprehensive, sustained STD control measures.

Policy makers, HIV prevention programme managers, and providers must focus initial implementation efforts on three key areas: (i) improving access to and quality of STD clinical services; (ii) promoting early and effective STD related healthcare behaviours; and (iii) establishing surveillance systems to monitor STD and HIV trends and their interrelation. Guide- 
lines addressing these areas have recently been published in the United States, ${ }^{80}$ and UNAIDS and the World Health Organisation are planning to develop analogous guidelines to assist developing country programmes.

Initial steps to ensure access to and quality of STD clinical services should, at a minimum, focus on public and private settings that serve individuals who are HIV infected or at high risk for HIV acquisition. These steps should include assessing and ensuring timely access to quality STD diagnostic and treatment services for symptomatic people seeking care; establishing or expanding STD screening in medical and non-medical settings for asymptomatic people who are at high risk for HIV infection and other STDs; and providing relevant training to programme managers and clinicians.$^{80}$ In industrialised countries, STD screening strategies in venues such as substance abuse treatment centres, correctional institutions, HIV counselling and testing sites, schools, and community centres in high morbidity areas may capitalise on the advent of urine based nucleic acid amplification tests and single dose antibiotic regimens. In developing countries, where resource constraints frequently preclude widespread use of aetiological tests, primary emphasis should be placed on assuring access to high quality STD clinical services for symptomatic people in medical and non-medical settings. This will require widespread training of providers in the use of algorithms for syndromic STD management, which perform well in the diagnosis of genital ulcers and urethritis. ${ }^{81}$ It will also necessitate re-evaluation of vaginal discharge algorithms which have limited sensitivity and specificity in detection of cervicitis, ${ }^{81}$ as well as a greater commitment to assure consistent availability of effective STD drugs at local levels. Providing HIV counselling, testing, and referral to individuals diagnosed with other STDs is clearly an important complementary strategy.

Promotion of early and effective STD related healthcare behaviours must begin to complement the important risk reduction messages that, in many parts of the world, currently focus almost exclusively on sexual behaviours. The critical new messages for individuals at risk for HIV infection and other STDs include (i) other STDs facilitate the spread of HIV infection, thus STD detection and treatment is an HIV prevention strategy; (ii) recognising and acting on STD symptoms are important; and, in settings where screening is feasible, (iii) most STDs occur without symptoms, so regular screening is vital. People must also be provided with specific information about sources of STD services. A complementary set of messages must be developed for providers. ${ }^{81}$

An essential condition for effective and cost effective implementation of STD treatment as an HIV prevention strategy is establishment at the local level of basic STD and HIV surveillance systems with linkages that permit policy makers, programme managers, and providers to determine, in their community, the extent of overlap between STD and HIV infected populations and, therefore, the relative importance locally of STD treatment in the mix of HIV prevention strategies. These systems should also provide information on the aetiological spectrum of STDs. These data must be analysed, disseminated, and used on a routine, timely basis to guide decision making as both HIV and STD epidemics evolve.

In summary, STD control is a central priority in its own right. Almost two decades into the most devastating pandemic of our times, we have strong evidence that early detection and treatment of other STDs can be a powerful addition to the HIV prevention arsenal in populations with substantial burdens of curable STDs, particularly in early HIV epidemics. While we must continue to refine our understanding of how best to implement STD control to prevent HIV transmission in specific populations, initial steps to assess potential impact and, where epidemiologically appropriate, incorporate STD treatment as part of a comprehensive HIV prevention strategy are clear. We must not hesitate any longer to take those steps.

The authors gratefully acknowledge the thoughtful input of Michael St Louis, and the outstanding assistance of Glenda Vaughn in manuscript preparation.

1 Centers for Disease Control and Prevention. Gonorrhea among men who have sex with men-selected sexually transmitted diseases clinics, 1993-1996. MMWR 1997;46:889-9.

2 Institute of Medicine. The hidden epidemic: confronting sexually transmitted diseases. Washington, DC: National Academy Press, 1997.

3 Panel on Reproductive Health, et al. In: Tsui AO, Wasserheit $\mathrm{JN}$, Haaga JG, eds. Reproductive health in developing countries: expanding dimensions, building solutions. Washington, DC: National Academy Press, 1997.

4 Landry DJ, Forrest JD. Public health departments providing sexually transmitted disease services. Fam Plan Perspect

5 Wasserheit JN. Epidemiological synergy. Interrelationships between human immunodeficiency virus infection and other sexually transmitted diseases. [Review] Sex Transm Dis 1992;19:61-77.

6 Clottey C, Dallabetta G. Sexually transmitted diseases and human immunodeficiency virus. Epidemiologic synergy? [Review] Infect Dis Clin N Am 1993;7:753-70.

7 Mastro TD, de Vincenzi I. Probabilities of sexual HIV-1 transmission. AIDS 1996;10 Suppl A:S75-82.

8 Kreiss JK, Coombs R, Plummer F, et al. Isolation of human immunodeficiency virus from genital ulcers in Nairobi prostitutes. F Infect Dis 1989;160:380-4.

9 Plummer FA, Wainberg MA, Plourde P, et al. Detection of human immunodeficiency virus type 1 (HIV-1) in genital ulcer exudate of HIV-1-infected men by culture and gene ulcer exudate of HIV-1-infected men by culture an
amplification [letter]. F Infect Dis 1990;161:810-11.

10 Ghys PD, Fransen K, Diallo MO, et al. The associations between cervicovaginal HIV shedding, sexually transmitted diseases and immunosuppression in female sex workers in Abidjan, Cote d'Ivoire. AIDS 1997;11:F85-93.

11 Dyer JR, Eron JJ, Hoffman IF, et al. Association of CD4 cell depletion and elevated blood and seminal plasma human immunodeficiency virus type 1 (HIV-1) RNA concentrations with genital ulcer disease in HIV-1-infected men in Malawi. F Infect Dis 1998;177:224-7.

12 Schacker T, Ryncarz A, Goddard J, et al. Frequent recovery of HIV-1 from genital herpes simplex virus lesions in HIV1-infected men. $7 A M A$ 1998;280:61-6.

13 Mole L, Ripich S, Margolis D, et al. The impact of active herpes simplex virus infection on human immunodefiherpes simplex virus infection on human im
ciency virus load. F Infect Dis 1997;176:766-70.

14 Spinola SM, Orazi A, Arno JN, et al. Haemophilus ducreyi elicits a cutaneous infiltrate of CD4 cells during experimental human infection. F Infect Dis 1996;173:394-402.

15 Stamm WE, Handsfield HH, Rompalo AM, et al. The association between genital ulcer disease and acquisition of HIV infection in homosexual men. $\mathcal{F} A M A$ 1988;260:142933.

16 Magro CM, Crowson AN, Alfa M, et al. A morphological study of penile chancroid lesions in human immunodeficiency virus (HIV)-positive and -negative African men with a hypothesis concerning the role of chancroid in HIV a hypothesis concerning the role of chancroid

17 Van Laer L, Vingerhoets J, Vanham G, et al. In vitro stimulation of peripheral blood mononuclear cells (PBMC) from HIV- and HIV+ chancroid patients by Haemophilus ducreyi antigens. Clin Exp Immunol 1995;102:243-50. 
18 Heng MC, Heng SY, Allen SG. Co-infection and synergy of human immunodeficiency virus-1 and herpes simplex virus-1. Lancet 1994;343:255-8.

19 Pleskoff O, Treboute C, Brelot A, et al. Identification of a chemokine receptor encoded by human cytomegalovirus as a cofactor for HIV-1 entry. Science 1997;276:1874-8.

20 Moss GB, Overbaugh J, Welch M, et al. Human immunodeficiency virus DNA in urethral secretions in men association with gonococcal urethritis and CD4 cell depletion. F Infect Dis 1995;172:1469-74.

21 Anderson DJ, O'Brien TR, Politch JA, et al. Effects of disease stage and zidovudine therapy on the detection of human immunodeficiency virus type 1 in semen [see comments]. $\mathscr{F} A M A$ 1992;267:2769-74.

22 Atkins MC, Carlin EM, Emery VC, et al. Fluctuations of HIV load in semen of HIV positive patients with newly acquired sexually transmitted diseases. BMF 1996;313 $341-2$

23 Cohen MS, Hoffman IF, Royce RA, et al. Reduction of concentration of HIV-1 in semen after treatment of urethritis: implications for prevention of sexual transmission of HIV1. Lancet 1997;349:1868-73.

24 Eron JJ, Jr, Gilliam B, Fiscus S, et al. HIV-1 shedding and chlamydial urethritis [letter; comment]. $\mathscr{f} A M A$ 1996;275: 36.

25 Mostad SB, Overbaugh J, DeVange DM, et al. Hormonal contraception, vitamin A deficiency, and other risk factors for shedding of HIV-1 from the cervix and vagina. Lancet 1997;350:922-7.

26 Clemetson DB, Moss GB, Willerford DM, et al. Detection of HIV DNA in cervical and vaginal secretions. Prevalence and correlates among women in Nairobi, Kenya. $\mathcal{F} A M A$ 1993;269:2860-4.

27 Kreiss J, Willerford DM, Hensel M, et al. Association between cervical inflammation and cervical shedding of human immunodeficiency virus DNA. F Infect Dis 1994 170:1597-601.

28 John G, Nduati R, Mbori-Ngach D, et al. Genital shedding of human immunodeficiency virus type 1 DNA during pregnancy: association with immunosuppression, abnormal cervical or vaginal discharge, and severe vitamin A deficiency. F Infect Dis 1997;175:57-62.

29 Levine WC, Pope V, Bhoomkar A, et al. Increase in endocervical CD4 lymphocytes among women with non-ulcerative sexually transmitted diseases. F Infect Dis $1998 ; 177: 167-74$.

30 Ho JL, He S, Hu A, et al. Neutrophils from human immunodeficiency virus (HIV)-seronegative donors induce HIV replication from HIV-infected patients' mononuclear cells and cell lines: an in vitro model of HIV transmission facilitated by Chlamydia trachomatis. $\mathcal{F}$ Exp Med 1995;181: 1493-505

31 Dallabetta GA, Miotti PG, Chiphangwi JD, et al. Traditiona vaginal agents: use and association with HIV infection in Malawian women. AIDS 1995;9:293-7.

32 Dickerson MC, Johston JJ, Delea TE, et al. The causal role for genital ulcer disease as a risk factor for transmission of
human immunodeficiency virus. An application of the human immunodeficiency virus. An application of
Bradford Hill criteria. Sex Transm Dis 1996;23:429-40.

33 Cameron DW, Simonsen JN, D'Costa LJ, et al. Female to male transmission of human immunodeficiency virus type 1 : risk factors for seroconversion in men [see comments] Lancet 1989;2:403-7.

33A Mbizvo MT, Machekano R, McFarland W, et al. HIV seroincidence and correlates of seroconversion in a cohort of male factory workers in Harare, Zimbabwe. AIDS 1996; 10:895-901.

34 Nopkesorn T, Mock PA, Mastro TD, et al. HIV-1 subtype E incidence and sexually transmitted diseases in a cohort of military conscripts in northern Thailand. $\mathcal{F} \mathrm{Acq}$ Immun Def Synd Human Retrovirol 1998;18:372-9.

35 Nelson KE, Eiumtrakul S, Celentano D, et al. The association of herpes simplex virus type 2 (HSV-2), haemophilus ducreyi, and syphilis with HIV infection in young men in northern Thailand. F Acq Immun Def Synd Human Retrovirol 1997;16:293-300.

36 Telzak EE, Chiasson MA, Bevier PJ, et al. HIV-1 seroconversion in patients with and without genital ulce disease. A prospective study. Ann Intern Med 1993;119: 1181-6.

37 Plummer FA, Simonsen JN, Cameron DW, et al. Cofactors in male-female sexual transmission of human immunodeficiency virus type 1 . F Infect Dis 1991;163:233-9.

38 De Vincenzi I. A longitudinal study of human immunodeficiency virus transmission by heterosexual partners. Eurociency virus transmission by heterosexual partners. EuroN Engl ₹ Med 1994;331:341-6.

39 Kassler WJ, Zenilman JM, Erickson B, et al. Seroconversion in patients attending sexually transmitted disease clinics. AIDS 1994;8:351-5.

40 Mehendale SM, Rodrigues JJ, Brookmeyer RS, et al. Incidence and predictors of human immunodeficiency virus type 1 seroconversion in patients attending sexually transmitted disease clinics in India. F Infect Dis 1995;172 1486-91.

41 Holmberg SD, Stewart JA, Gerber AR. Prior herpes simplex virus type 2 infections as a risk factor for HIV infection. ҒAMA 1988;259:1048-50.

42 Keet IPM, Lee FK, van Griensven GJP, et al. Herpes simplex virus type 2 and other genital ulcerative infections simplex virus type 2 and other genital ulcerative infections 66:330-3.

43 Kingsley LA, Armstrong J, Rahman A, et al. No association between herpes simplex virus type-2 seropositivity or ano- genital lesions and HIV seroconversion among homosexual men. F Acqu Immun Def Syn 1990;3:773-9.

44 Kuiken CL, van Griensven GJ, de Vroome EM, et al. Risk factors and changes in sexual behavior in male homosexuals who seroconverted for human immunodeficiency virus antibodies. Am F Epiderm 1990;132:523-30.

45 Craib KJ, Meddings DR, Strathdee SA, et al. Rectal gonorrhoea as an independent risk factor for HIV infection in a cohort of homosexual men. Genitourin Med 1995;71:150 4 .

46 Dominguez KL, Ellerbrock TV, Harrington PE, et al. Risk factors for HIV seroconversion among young women in a rural community in the southeastern United States. XI International Conference on AIDS, Vancouver, July 7-12, 1996; abstract No C 222.

47 Darrow WW, Echenberg DF, Jaffe HW, et al. Risk factors for human immunodeficiency virus (HIV) infections in homosexual men. Am 7 Public Health 1987;77:479-83.

48 Otten MW Jr, Zaidi AA, Peterman TA, et al. High rate of HIV seroconversion among patients attending urban sexually transmitted disease clinics. AIDS 1994;8:549-53.

49 Kilmarx PH, Limpakarnjanarat K, Saisorn S, et al. Incident HIV-1 infection and sexually transmitted diseases among female sex workers in Upper Northern Thailand (abstract). In: Fourth International Congress on AIDS in Asia and the Pacific. Manila, Philippines, 1997: C(P)065.

50 Plourde PJ, Pepin J, Agoki E, et al. Human immunodeficiency virus type 1 seroconversion in women with genital ulcers. F Infect Dis 1994;170:313-17.

51 Laga M, Manoka A, Kivuvu M, et al. Non-ulcerative sexually transmitted diseases as risk factors for HIV-1 transmission in women: results from a cohort study [see comments]. AIDS 1993;7:95-102.

52 Kapiga S, Lyamuya EF, Lwihula GK, et al. The incidence of HIV infection among women using family planning methods in Dar-es-Salaam, Tanzania. AIDS 1998;12:75-84.

53 Taha TE, Hoover DR, Dallabetta GA, et al. Bacterial vaginosis and disturbances of vaginal flora: association with
increased acquisition of HIV. AIDS 1998;12:1699-706.

54 Weir SS, Feldblum PJ, Roddy RE, et al. Gonorrhea as a risk factor for HIV acquisition. AIDS 1994;8:1605-8.

55 Sewankambo N, Gray RH, Wawer MJ, et al. HIV-1 infection associated with abnormal vaginal flora morphology and bacterial vaginosis. Lancet 1997;350:546-50.

56 Miettenen OS. Proportion of disease caused or prevented by a given exposure, trait, or intervention. Am $\mathcal{f}$ Epidemio 1974;99:325-32.

57 Vittinghoff E, Padian NS. Attributable risk of exposures associated with sexually transmitted disease. I Infect Dis 1996;174 (Suppl 2):S182-7.

58 Hayes RJ, Schulz KF, Plummer FA. The cofactor effect of genital ulcers on the per-exposure risk of HIV transmission in sub-Saharan Africa. [Review] f Trop Med Hyg 1995;98: in sub- $1-8$.

59 Boily MC, Anderson RM. Human immunodeficiency virus transmission and the role of other sexually transmitted diseases. Measures of association and study design. Sex Transm Dis 1996;23:312-32.

60 Boily MC. Transmission dynamics of co-existing chlamydia and HIV infections in the United States. In: The hidden epidemic: confronting sexually transmitted diseases. Washington, DC: National Academy Press, 1996:C1-13.

61 May R, Anderson R. Transmission dynamics of HIV infection. Nature 1987;326:137-42.

62 Boily MC, Brunham RC. The impact of HIV and other STDs on human populations. Are predictions possible? Infect Dis Clin N Am 1993;7:771-92.

63 Robinson NJ, Mulder DW, Auvert B, et al. Proportion of HIV infections attributable to other sexually transmitted diseases in a rural Ugandan population: simulation mode estimates. Int F Epidemiol 1997;26:180-9.

64 Garnett GP, Anderson RM. Strategies for limiting the spread of HIV in developing countries: conclusions based on studies of the transmission dynamics of the virus. $f$ Acquir Immun Defic Syndr Hum Retrovirol 1995;9:500-13.

65 Over M, Piot P. Human immunodeficiency virus infection and other sexually transmitted diseases in developing countries: public health importance and priorities for resource allocation. $\mathcal{F}$ Infect Dis 1996;174 (suppl 2):16275.

66 World Bank. Confronting AIDS: public priorities in a global epidemic. Washington, DC: International Bank for Reconstruction and Development/World Bank 1997:1-14.

67 Mertens TE, Hayes RJ, Smith PG. Epidemiological methods to study the interaction between HIV infection and other sexually transmitted diseases. [Review] AIDS 1990;4:57-65.

68 Laga M, Diallo MO, Buve A. Interrelationship of sexually transmitted diseases and HIV: where are we now? AIDS 1994;8 (Supp1 1):S1 19-24.

69 Hayes RJ, Wawer M, Gray R, et al. Randomised trials of STD treatment for HIV prevention: report of an international workship. Genitourin Med 1997;73:432-43.

70 Nkowane BM, Lwanga SK. HIV and design of intervention studies for control of sexually transmitted diseases. AIDS 1990;4 (Suppl 1):S123-6.

71 Laga M, Alary M, Nzila N, et al. Condom promotion, sexually transmitted diseases treatment, and declining incidence of HIV-1 infection in female Zairian sex workers. Lancet 1994;344:246-8.

72 Plummer F. HIV and STD incidence in a sex worker cohort:1985-1997. Presentation at the UNAIDS-WHO 
Consultation on STD Interventions for Preventing HIV: what is the Evidence? Geneva: WHO, 14-16 Octobe 1998.

73 Levine WC, Revollo R, Kaune V, et al. Decline in sexually transmitted disease prevalence in female Bolivian sex workers: impact of an HIV prevention project. AIDS 1998; 12:1899-906.

74 Grosskurth H, Mosha F, Todd J, et al. Impact of improved treatment of sexually transmitted diseases on HIV infection in rural Tanzania: randomised controlled trial [see comments]. Lancet 1995;346:530-6.

75 Mayaud P, Mosha F, Todd J, et al. Improved treatment services significantly reduce the prevalence of sexually transices significantly reduce the prevalence of sexually transmitted diseases in rural Tanzania: results of a randomized
controlled trial. AIDS 1997;11:1873-80.

Gilson I, Mkanje R, Grosskurth $\mathrm{H}$, et al. Cost-effectivenes of improved treatment services for sexually transmitted diseases in preventing HIV-1 infection in Mwanza Region, Tanzania. Lancet 1997;350:1805-9.
77 Wawer MJ, Gray RH, Sewankambo NK, et al. Results of a randomized, community trial of STD control for AIDS prevention, Rakai District, Uganda: reductions in STD are not associated with reduced HIV incidence. Lancet, in press.

78 Laga M, Dallabetta G. Treating the whole syndrome. Lancet 1997;350 (suppl III): 25 .

79 Cohen MS. Sexually transmitted diseases enhance HIV transmission: no longer a hypothesis. Lancet 1998;351 (suppl III):5-7.

80 Centers for Disease Control and Prevention. HIV prevention through early detection and treatment of other sexually transmitted diseases-United States. $M M W R$ 1998;47(No RR-12):1-24.

81 Dallabetta GA, Gerbase AC, Holmes KK Problems, solutions, and challenges in syndromic management of sexually transmitted diseases. Sex Transm Infect 1998;74 (Suppl 1):S1-11. 